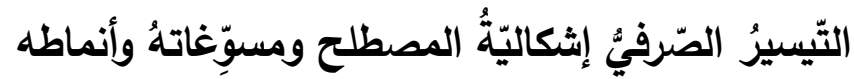

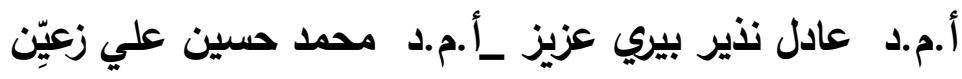

_جامعة كربلاء _ كلية التربية _ قسم اللغة العربية

المقدمة

الحمدُ للهِ ميِّر الفهم لعباده المتقين، والصلاة والعلام على أفصح ناطقي بالضاد بين العالمين، وسيدنا

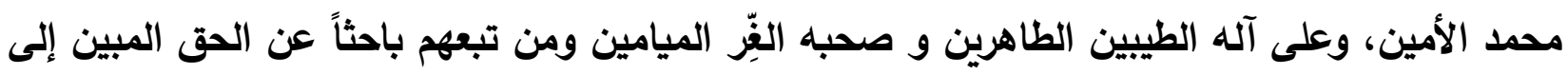
يوم الدين. وبعدُ:

(فإنَّ الكلماتِ هيَ التي تمهِّد الطريق للأفعالِ وتثيرُ مناقثاتِ الغدِ) تلك فحوى مقولة للأديب التشيكي (فرانز كافكا) وهو يتحدّث عن اللغة بوصفها خيطاً يوصل الحاضر بالماضي فهي أمانة يحملها الخَلَف عن السَّلف بوصفها لصيقة بالأمة فهي أداتها الثقافية ووسيلتها المعرفية الأساس وذاكرتها التأريخية وكذا لغتنا العربية ينطبق عليها هذا الوصف إذ هي لغة حية تستجيب لمتطلبات العصر السياسية ، والاجتماعية

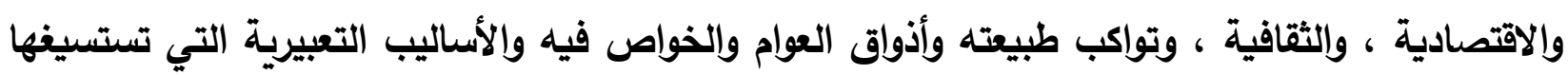
النخب العلمية والثقافية ، وهذه الاستجابة لا تتحقق إلا عن طريق إعادة ترتيب الجهد اللغوي عموماً على وادي

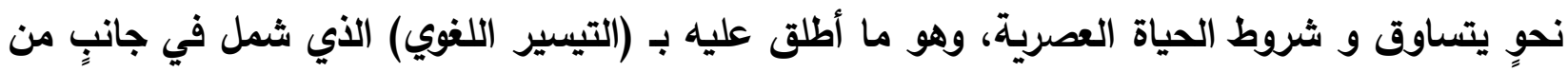
جوانبه التيسير الصرفي المتعلّق ببنية المفردة العربية وإنصهارها في قوالب تنسجم ومظاهر التطور

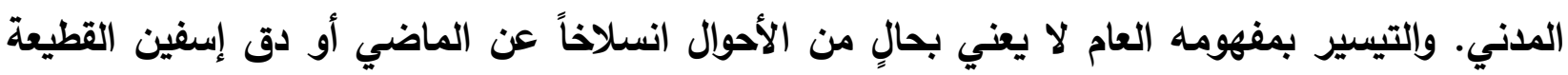

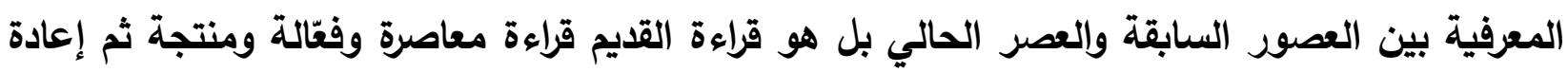

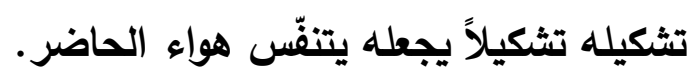
على أنّ موضوع (التيسير الصرفي) لم يلقَ ما لقيه (التيسير النحوي) من عناية علماء اللفة العربية

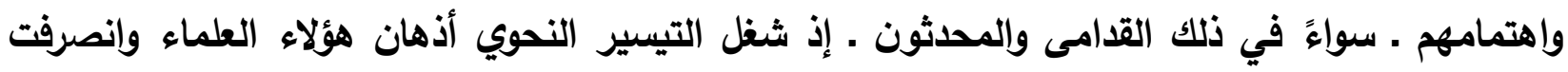
أقلامهم إلى تأليف مصنّفاتٍ في هذا الميدان حملت بعضها عنوانات تندرج تحت هذا الباب، في حين ضمّ

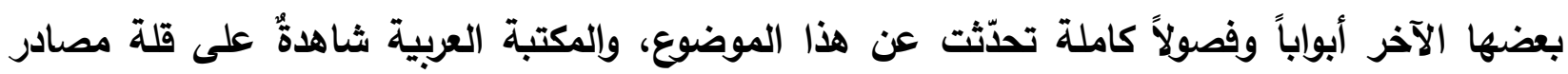
التيسير الصرفي • إن لم نقل ندرتها ـ ولعلَّ البواعث التي تكمن من وراء عدم إفراد المؤلفين مصنّفات 
مستقلة تعالج هذا الموضوع تعود إلى أنّ ارتباط النحو بالتركيب العربي في جمله الاسمية والفعلية وأثباه

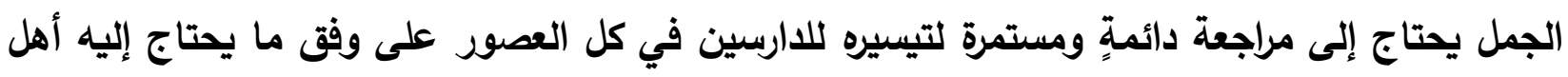

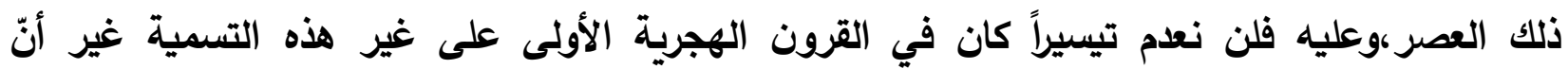
الضرورة اقتضت أن يلجأ علماء اللغة القدامى والمحدثون إلى تيسير أبوابٍ كثيرة في النحو بغية شيوعها بين أوساط الدارسين. وإذا ما سلّمنا بوجود التيسير النحوي والآراء المخالفة له؛ فإنّ الصرف وهو الوجه الثاني للعربية كان ملازماً للنحو منذ نشأته على أننا قد نجد تيسيراً محدوداً لأبواب من علم الصرف عند القدماء مراعاة لمقتضيات الحاجة؛ لارتباط الصرف ببنية الكلمة مما يصعب التيسير فيها. ومع هذا سيجد الدارس المتمعّن

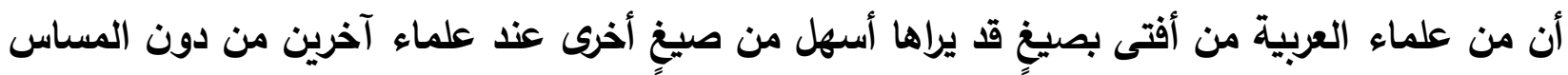
بالقواعد الأساسية لعلم الصرف نحو ما نجده في قواعد الإعلال والإبدال والإدغام والجموع.... ولو توخّينا الدقة في هذا الأمر لوقفنا في بطون كتب عُنيت بالتيسير النحوي وقد ضمّت عنوانات أو موضوعات تندرج تحت ميدان التيسير الصرفي الذي هو جزء لا يتجزً من النحو العربي عموماً.

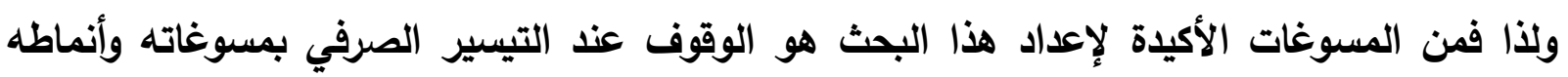

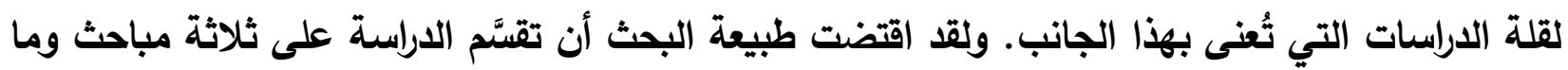

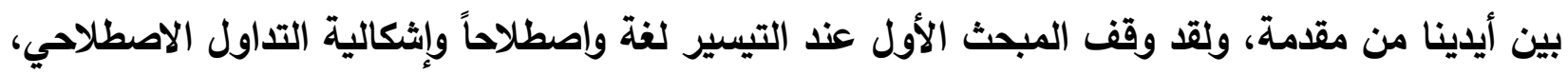
في حين وقف المبحث الثاني عند أهم مسوّغات الفريق القائل بذلك التيسير وحجههم فيه والفريق المناهض لهذا التيسير وإيراده الحجج المخالفة لحجج المريدين له وبيّن كلُ فريقٍ غايتَهُ من موضوع الخلاف. ثم عرض المبحث الثالث أهم أسس التيسير وأنماطه وقد تمّ اختيار قرارات مجمع اللغة العربية بالقاهرة أنموذجاً لهذه الأنماط. وبقدر ما يتسع البحث اجتهـ الباحثان في تحليل مسوّغات التيسير وغاياته وأنماطه. والتعليق على ما فا أفادتنا به قرارات المجمع. واختُتِمِ البحث بخلاصة أوجزت ما تقدّم فضلاً على ما أثشرنا إليه من نتائج.

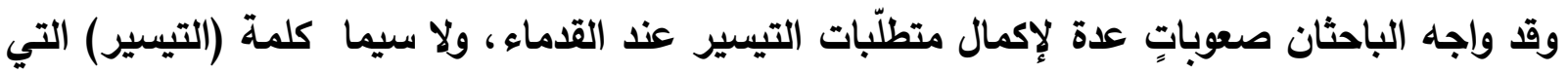

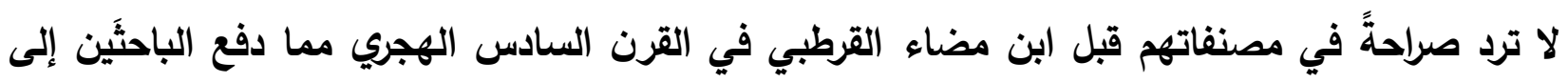
استنتاج وتأويل ما يمكن تأويله من آراء القدماء في هذا هُ الثأن. والحمدُ لله أولاً وآخراً... 
التيسير لغة: مصدر مأخوذ من الفعل (يَسَّر) يُقال:)(( تَيَسَّر الثيء واستيسر بمعنى تَسَهَّلَ، ويُقال: أخذ ما تيسَّر وما استيسر بمعنى تسهّل، وهو ضد ما تعسَّر والتتوى، ويسّره هو: سهّله،، وحكى سيبويـه: يسَّره

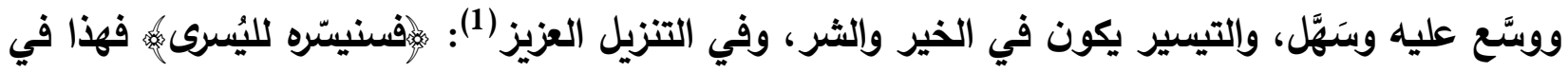

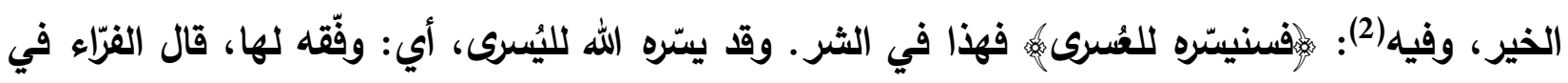

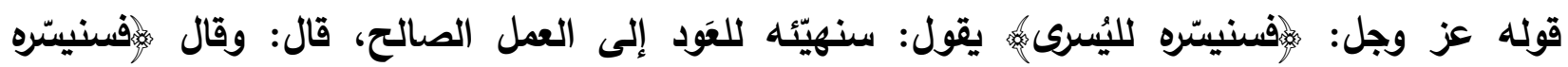

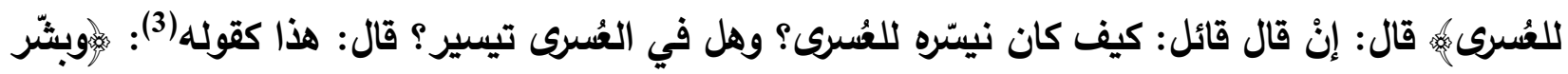

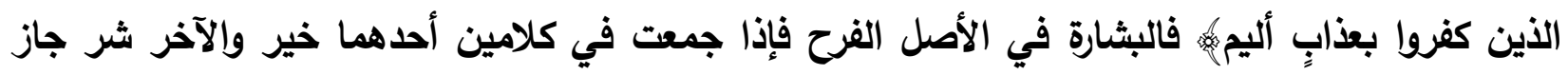

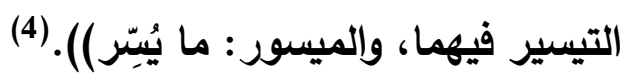
أما (التيسير) اصطلاحاً فهو: الترخّص في الأمر وعلدم الاستقصاء.(5) وحينما بحثنا في كتب علماء اللغة المحدثين عن تعريفٍ للتيسير لم نجد هذه الكلمة بمعزل عن كلمة (النحوي) أي أنّ هؤلاء العلماء ينظرون إلى تعريف (التيسير النحوي) على أنه مصطلح واحد ولا يأتون بكلمة (التيسير) منفردة وإخترنا بعض هذه التعريفات محاولين تطبيقها على مفهوم (التيسير الصرفي) بما يتعلّق بجذور الكلمات وصيغها واشتقاقاتها.

قيل فيه: هو تكيف الصرف مع المقاييس التي تقتضيها التربية الحديثة عن طريق تبسيط الصورة التي

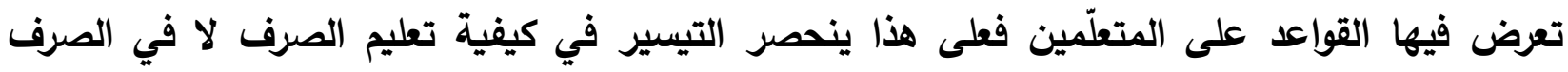
ذاته(6) ويراه فريق من الباحثين: تغييراً في الأحكام والقواعد بحيث تحصل السهولة المطلوبة إذ إنّ غاية التيسير: التسهيل والقضاء على كل صعوبة وعُسر مما يمسُّ بنية الكلمة ممّا قالته العرب ولم يثُبه التكلّف أو التعقيد. (7) وقد قيل غير ذلك في تعريف التيسير ولكن بسبب تعدد الرؤى الفكريّة التي توخّت السهولة والتيسير في هذا الميدان ازدادت في مقابل ذلك صعوبة تحديد مفهوم دقيق للتيسير، بَيد أننا لا نعدم أن نقف عند جوهر

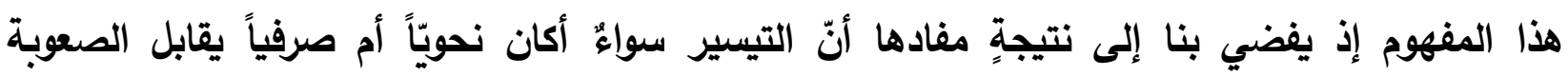

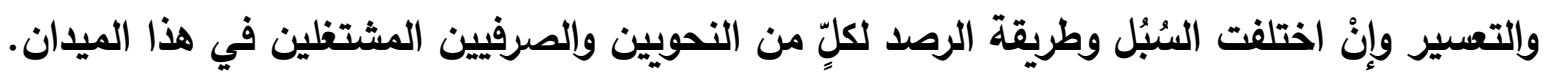

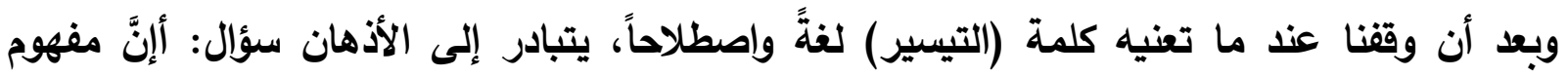


(التيسير) الأي يراد منه تسهيل علوم اللغة العربية مرادفُ لمصطاحات قد عُنونت بقسم منها كتب المؤلفين

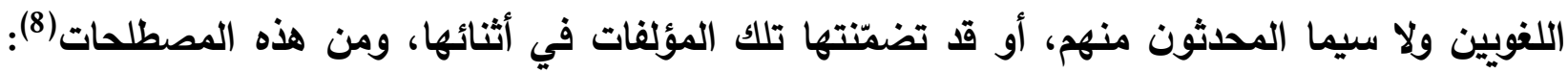

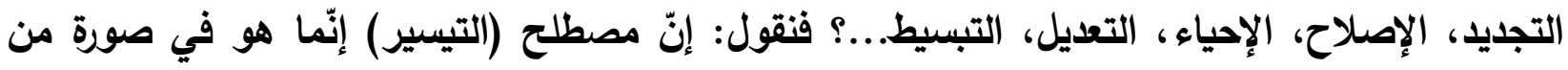
الصور مرادفُ في غايته للمصطلحات التي ذكرناها مع ملاحظة الفروق اللغوية في معاني كل مصطلح، وهو يقترب في مفهومه العام من هذه المصطلحات، ونجد أن (التجديد) اتجاه يدعو إلى تجاوز فكرة

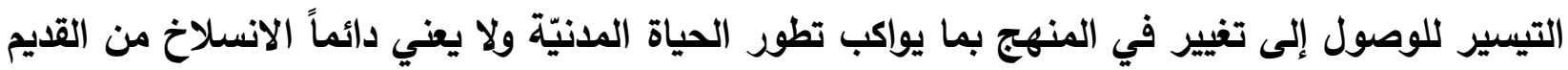
والعزوف عنه برمته بل هو محاوية لتفسير القديم تفسيراً جديداً يلائم العصر ويُبقي على القديم، وهذا ما فعله بعض الباحثين من أصحاب التيسير، أما مصطلحات: الإحياء،والإصلاح، والتعديل فهي خطوات حديثة للصيغ القديمة بإحيائها من ركامها القديم أولاً وإصلاح ما ينبغي إصلاحه على وفق الحياة المعاصرة وتعديل ذلك بما يتوجب تغييره ليناسب المقام من دون الإخلال بمنهج العرب القدماء في القياس الصرفي العربي. أما (التبسيط) فإنّه نظيرٌ لما تقدّم من مصطلحات فضلاً على أنه توجيه الطلبة الناشئين إلى دراسة

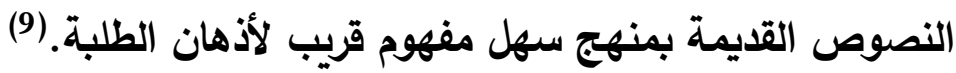
وقد كانت لعلماء اللغة المحدثين الداعين إلى التيسير مواقف متباينة من هذه المصطلحات فقسمٌ منهم

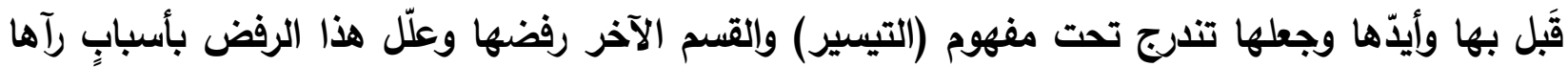

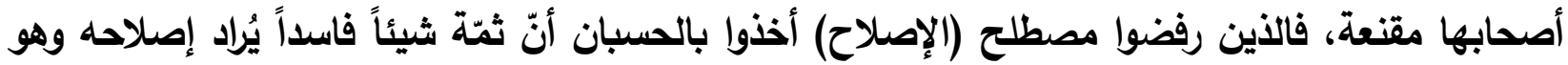
ما لا ينطبق على علوم العربية ومن ضمنها علم الصرف، في حين أن الذين رفضوا مصطلح (التجديد) ركنوا إلى حجّةٍ مفادها أنَّ كل قديم قد أكل الدهر عليه وشرب بحاجة هُة إلى تجديد وهم بهذا يريدون أن يبيّنوا

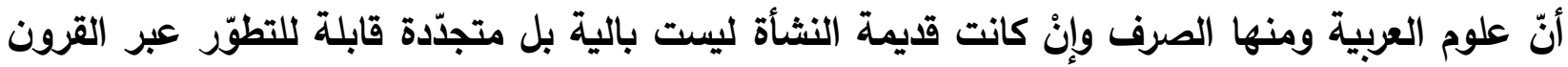
المتطاولة(10) على أنّا نتلمّس في رأي بعض الباحثين أنَّ مصطلح (التجديد) يكاد يكون مرادفاً للتيسير بيد

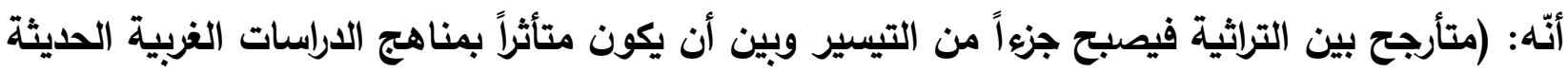

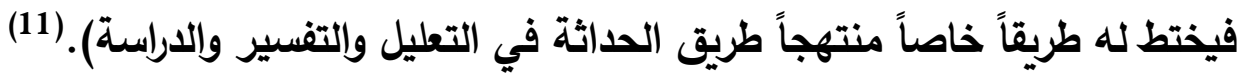
على أنّ بعض الباحثين قد جعل التجديد والإصلاح خطوةً تسبق التيسير اعتماداً على أن التيسير وحده

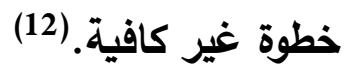

والذي يعنينا فضلاً على ما تقدّم من إثكالية المصطلح رصد نثأة التيسير الصرفي، وفي هذا نقول: إنّ الثعور بصعوبة علوم اللغة العربية ولاسيّما النحو والصرف ليس وليد العصر الحديث بل تعود

جذوره مع نشأة تلك العلوم، وهذه الصعوبة يمكن أن نعزوها لأسبابٍ عدة منها: أولاً: إنّ من أهم الأسباب التي تقف وراء صعوبة علوم اللفة العربية تأثر علماء العربية الأوائل 
بالتيارات الفكرية التي واكبت عصر تدوين اللغة وتقعيدها أولئك العلماء. وتأثر هؤلاء العلماء بهذه التيارات

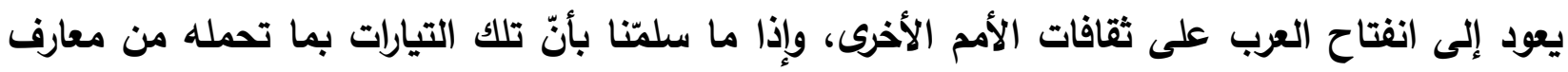

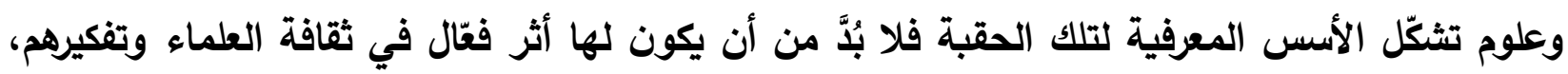

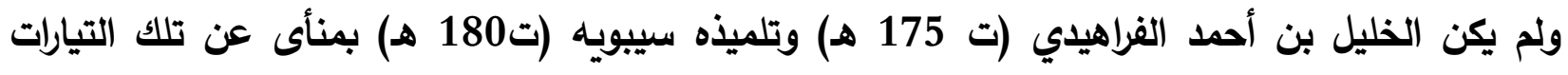

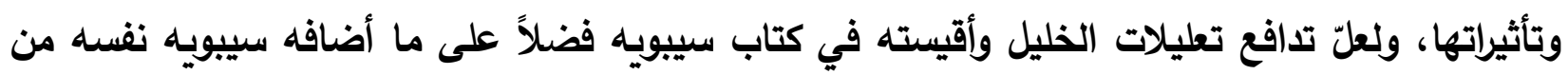

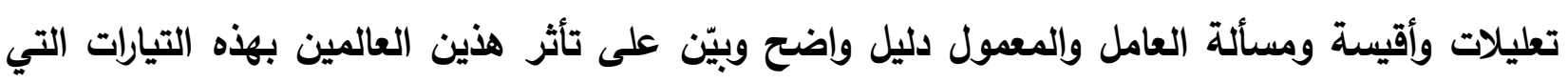
أشرنا إليها. على أنّ تأثير التيارات الفكرية لم يقتصر على الخليل وسيبويه فقط بل كان فيل بادياً على مؤلفات كثير من العماء منذ مطلع القرن الثالث الهجري. (13) ثانياً: ويمكن إرجاع الصعوبة التي اكتنفت مؤلّفات اللغويين الأوائل إلى ما يمكن أن نسمّيه (بدايات

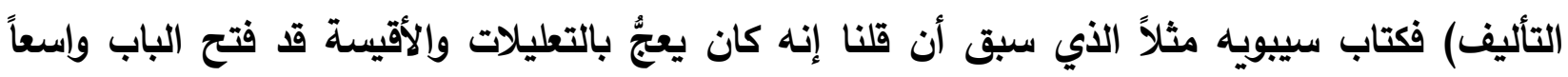

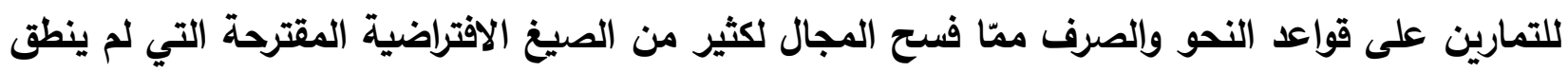

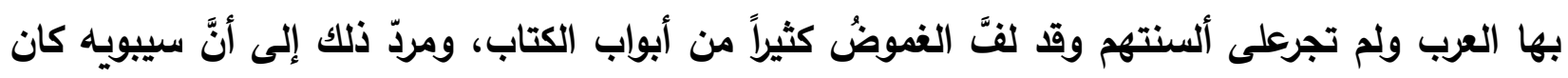

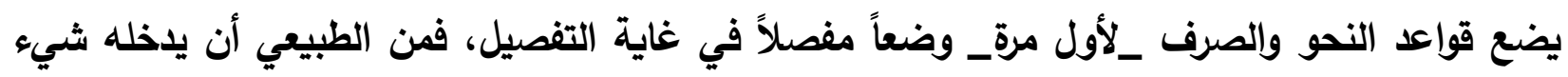
من الإبهام والغموض في بعض العبارات، وربّما يمكن إرجاع جوانب بعض الغموض والتعقيد إلى تلميذ

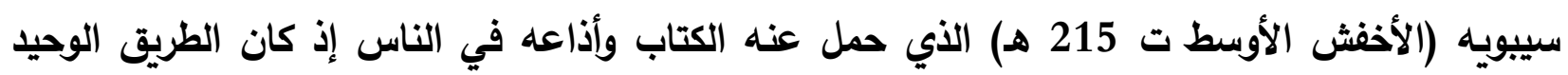

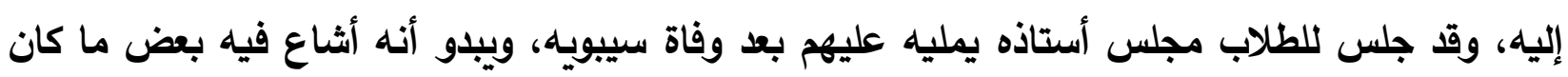

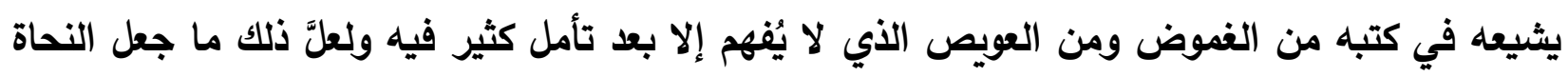

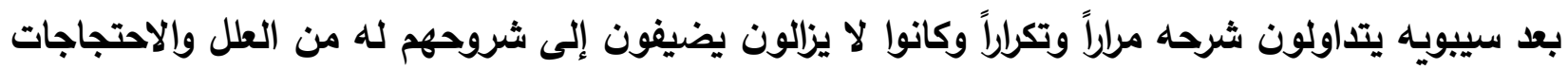

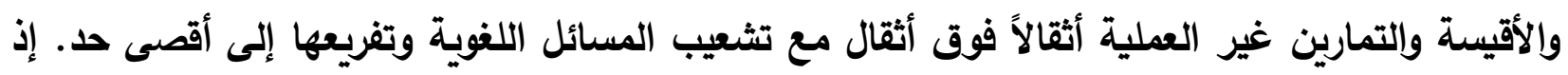
تتحول بعض شروح الكتاب إلى ما يشبه موسوعات لغوية كبرى على نحو ما نجده عند السيرافي (ت 368

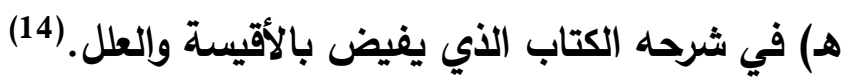
ثالثاً: وقد يتعمّد المؤلِّف نفسه أن يكون كتابه صعباً عسير الفهم على القارئ، وهذا التعمّد مرده إلى

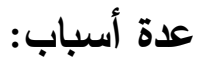
1- سبب ماديٌّ محض إذ يبتفي من ورائه المؤلِّف التكسّب من تأليف مصنّفاته بجعل تلك المصنفات

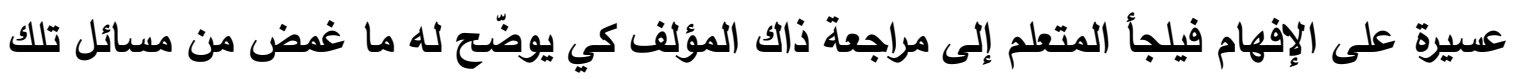

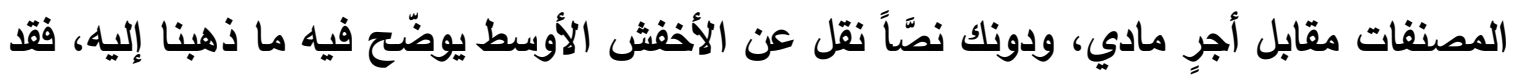

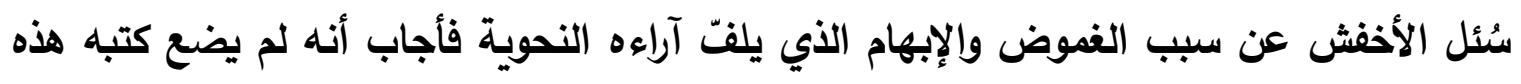


لله فهي ليست كتب دين بل هي كتبّ ذُهِبَ بها إلى التكسُب ولا يتحقّق هذا الههف إلا إذا كان النحو عسيراً صعباً. (15)

2- سبب معنوي ونعني به أنَّ المؤلف من خلال جعل مؤلفاته صعبة عصيّة على الفهم يحاول أن

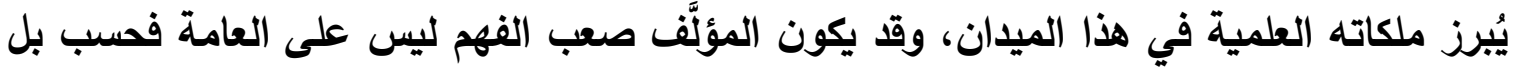

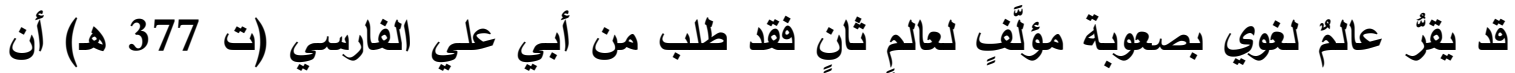

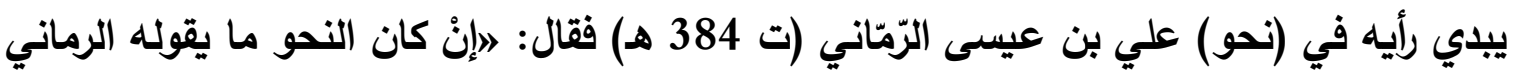

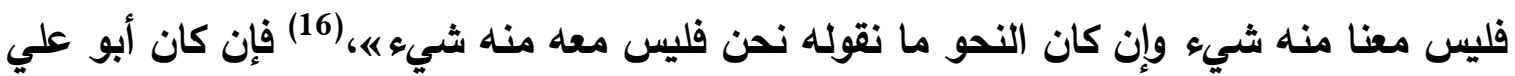
الفارسي وهو العالم اللغوي المعروف قد أقرَّ بصعوبة نحو الرماني فما بالك بالعامةٌ ومن كان مقرّاً

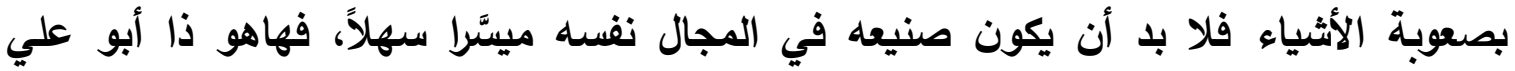

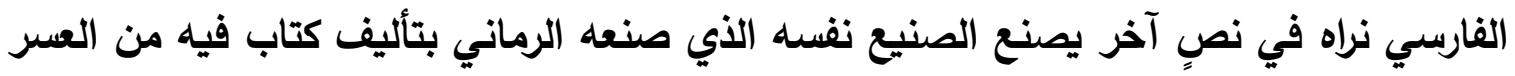

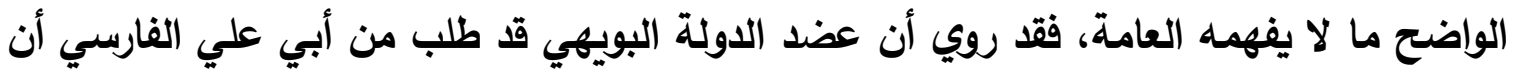

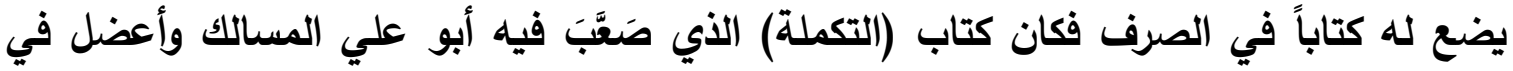

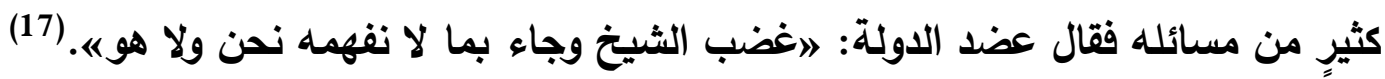
3- ومن أسباب صعوبة العربية على نحوٍ تحتاج معه إلى تيسير :السعة والتجدد ،فجميع ألفاظ اللغة

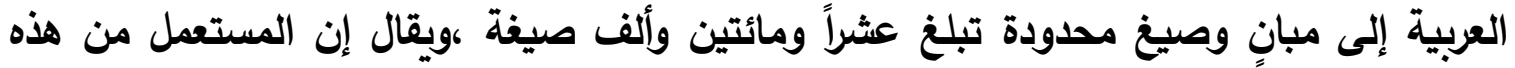
الأوزان مائة وعشرون وزناً فقط" إن، وهذا إن دلّ على شيء فهو يدل على الفجوة الواسعة بين الواقع والممكن ،وكل ذلك يحتاج إلى الإحاطة بالممكن كيما يتمكن اللغوي من رفد المستجدات

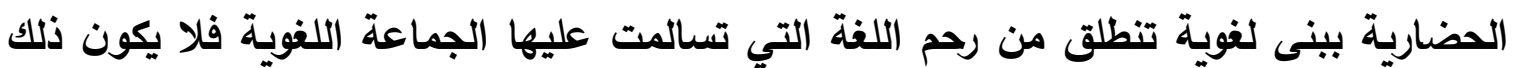

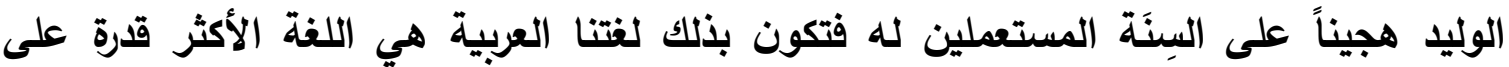
التواصل بفضل قدرتها الاستيعابية والمتجدة على نحوِ يتلاءم ومتطلبات كل عصر ، وبذلك تنمو

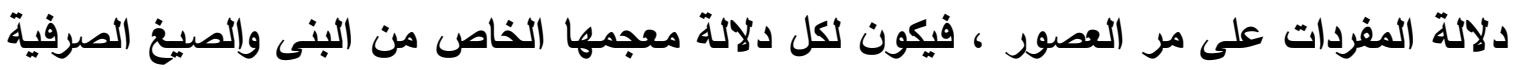

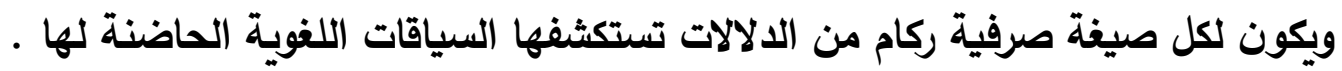
إنَّ حبَّ العرب للفتهم واعتزازهم ببلاغتهم فضلاً على توجههم لخدمة القرآن الكريم على وفق مانق الانتماءات المذهبية لهم جعلهم يشكّلون مدارس لغوية كان لكل مدرسة منها سمات خاصّة وطوابع مميزة فتح باب السباق في الاجتهاد والتدليل على صحة ما يذهبوا إليه على نحوٍ خلق لنا تراثاً جمّاً يصعب الإحاطة به ، وخلق مساحة مرجعية واسعة للغوي المعاصر كي يتفحص في ضوئه المططيات الحضارية المعاصرة ،الأمر الذي يجعله دائب البحث. 
يضاف إلى ذلك سعة العربية ، وكثرة علمائها ، فتح باب التمييز الذي يستلزم الاختلاف مع

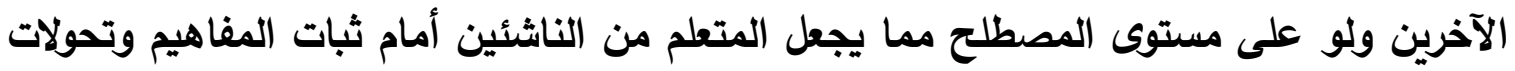
المصطلح. إنَّ ما قدمناه من صعوبات رافقت نثأة علوم اللغة العربية قد تكون هي الصعوبات الواضحة الملامح ولا نعدم وجود غيرها ولكننا توقِّنا عند أبرزها إذ كانت عاملاً رئيساً في ظهور التهاه الاتجاه

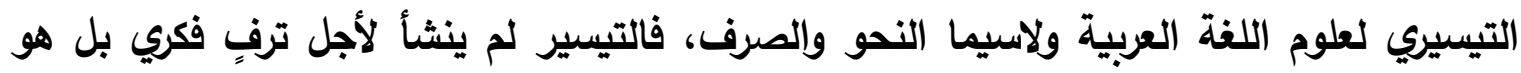

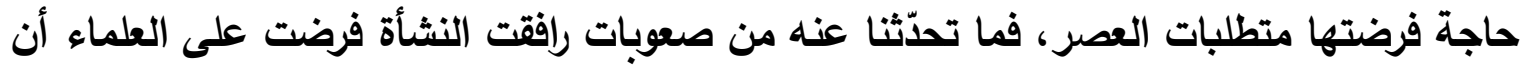
ييسّروا ما استطاعوا سواءٌ أكانت الصعوبات مرافقة لمؤلفاتهم أم كانت مرافقة لمؤلفات علماء

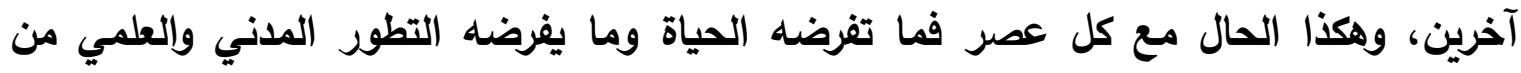
متطلّبات تجعل العلماء يفكرون في تقديم ما ييسّر على المتلقي من تعابير وصيغ تجعله يساير تلك المتطلّبات بلغةٍ سهلة مبسّطة لا تعقيد فيها، ولو أردنا أن نتتبّع المراحل التي مرَّ بها التيسير

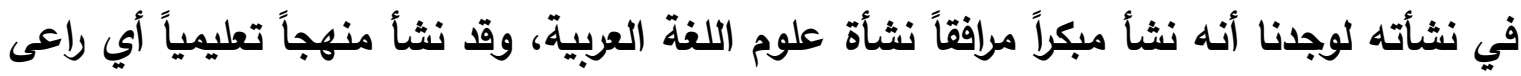

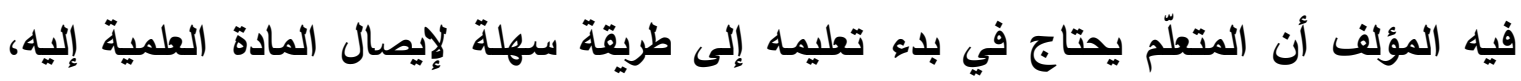

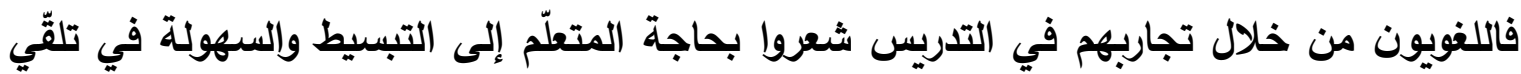
المادة العلمية، وما صنيع خلف الأحمر (ت 180 هـ) صاحب أول كتاب تعليمي وصل إلينا حينما أثار في مقدمة كتابه إلى هذا الإحساس إلا دليل واضح على ما قلناه، جاء في مقدمة كتابه:

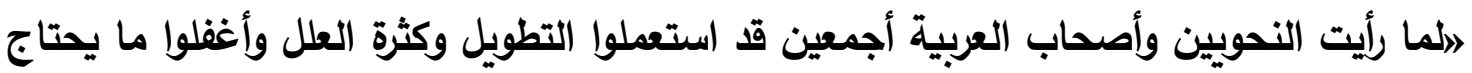
إليه المتعلّم المتبلّغ في النحو من المختصر والطرق العربية وإلمأخذ الذي يخف على المبتدئ حفظه ويعمل في عقله ويحيط به فهمه فأمعنت النظر والفكر في كتابٍ أؤلفه وأجمع فيه الأصول

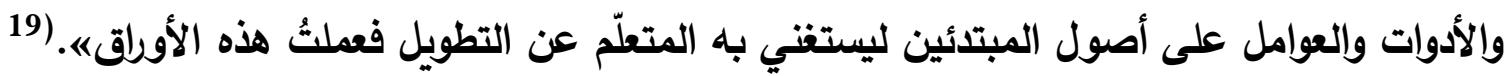

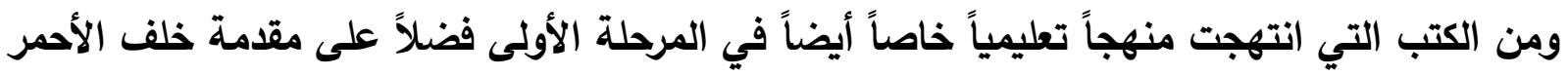
نجد مختصر الجرمي (ت 225هـ) ومختصر ابن شقير والموجز لابن السرّاج (ت 316 هـ) والجمل للزجاجي

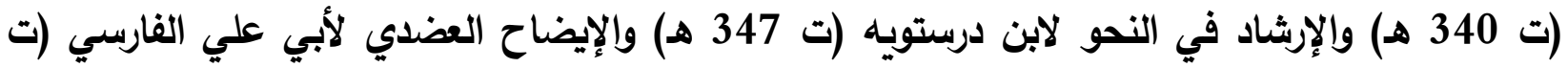
377 هـ) ثم كتاب اللمع لابن جني (ت 392 هـ) ثم المفصّل للزمخشري (ت 538 هـ) أما في المرحلة

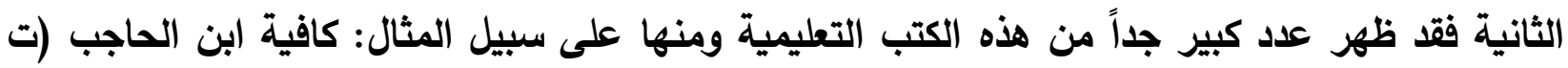
646 هـ) وكتب ابن مالك (ت 672 هـ) وأبي حيان (ت هـ 745 هـ) وابن هشام (ت 761 هـ) وغير ذلك الكثير من الكتب التعليمية(20) التي كان الغرض منها شرح المادة اللغوية شرحاً مبسّطاً وتقرببها إلى أذهان 
المتعلّمين بعيداً عن الغموض والتعقيد، ويمكن إرجاع سبب ظهور مثل هذه المصنّفات إلى إحساس

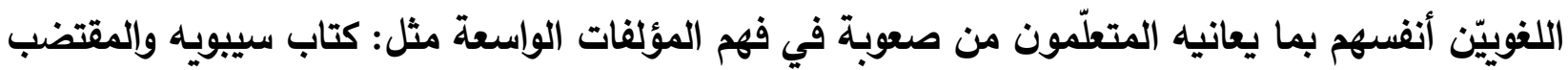

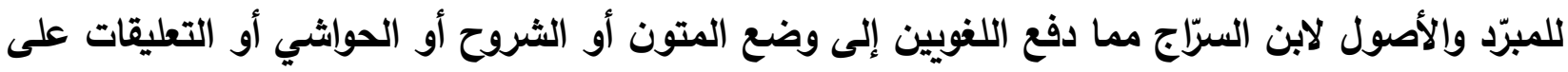

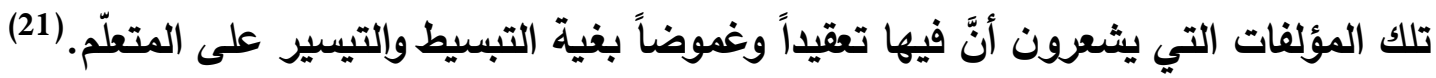
ونلاحظ أنَّ الباحث المعاصر قد جعل قسماً من هذه المؤلفات في جملة المؤلفات التعليمية الميسّرة

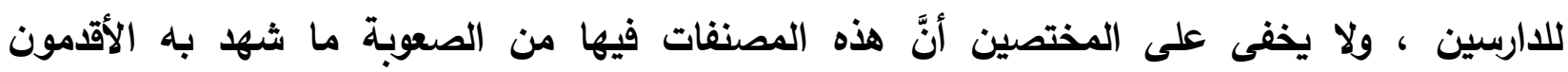
والمحدثون حتى لجؤوا إلى شرحها ، فالكافية لابن الحاجب مثلاً قد شرحت مرات كثيرة ،وكذلك كان شأن

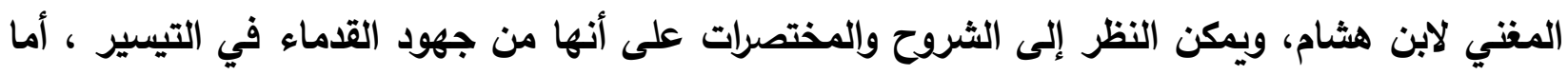

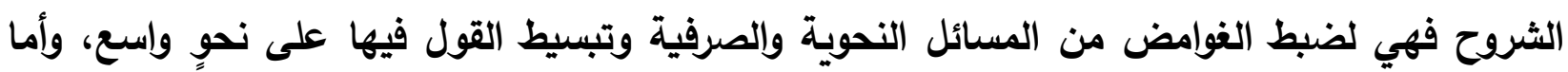

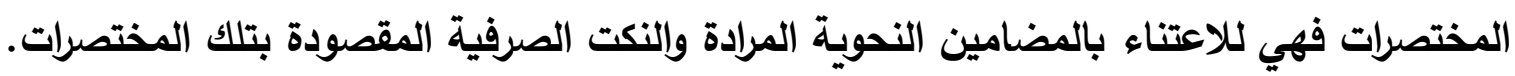

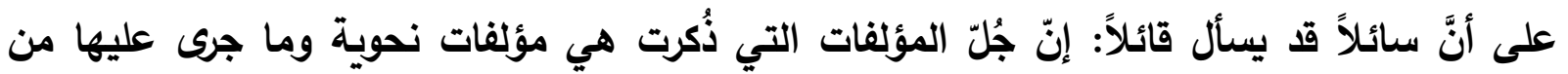

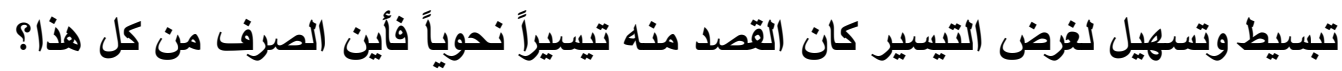

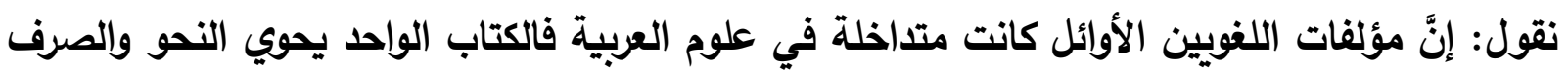
والصوت والبلاغة فضلاً على نصوصٍ من القرآن الكريم والعديث النبوي الثريف والثعر العربي والأمثال... وعلى الرغم من ظهور كتب الصرف مستقلة عن مباحث النحو فيما بعد فقد ظلت النظرة الكلية لمباحث العربية من نحو وصرف وصوت.. سائدة عند اللغويين العرب في فهمهم لمفهوم النحو ويتّضح ذلك جلياً في تعريف ابن جني للنحو إذ يقول عنه: "هو انتحاء سمت كلام العرب في تصرّفه من إعرابٍ وغيره كالتثية والجمع والتحقير والتكسير والإضافة والنسب والتركيب وغير ذلك ليلحق من ليس من أهل اللغة العربية بأهلها في الفصاحة فينطق بها وإن لم

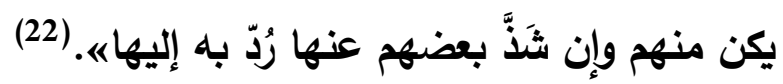
إنَّ هذا التعريف يكشف عن موقف اللغويين من مفهوم النحو فابن جني كان يضع تحت عنوان (النحو)

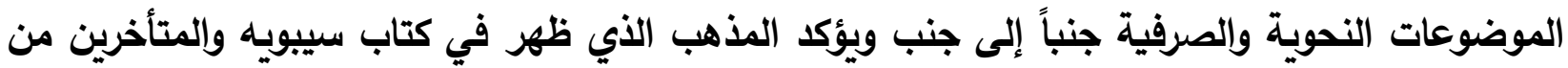

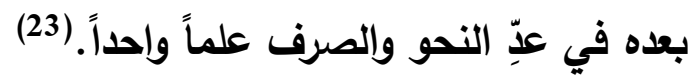
عليه يمكن القول إنّ ما كان يجري على النحو من إجراءات لغرض التيسير كان للصرف نصيب منه بارجة أقل وإن اقتصر المصطلح على النحو بالقول:( التيسير النحوي) ولكن لا يُنكر أنَّ التيسير النحوي

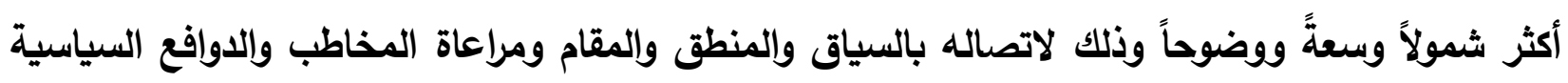
أو الاجتماعية أو الثقافية أو العقائدية، وقد ماثل التيسير الصرفئ التيسيرَ النحويَ في أوجه الاختصار 
والتغيير في الاستعمال من دون أن يصل إلى مستواه؛ لأنَّ التيسير الصرفي يتعلّق بينية الكلمة ومن

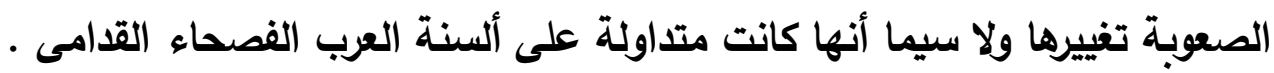

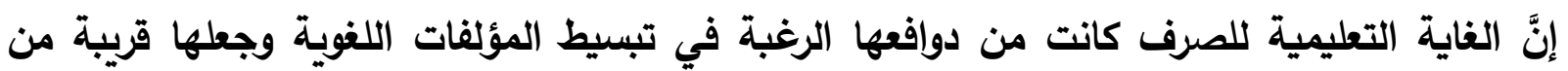
أذهان المتعلمين وتسهيل حفظها وقد عبّر عن هذه الرغبة كثير من اللغويين في مقدمات كتبهم ملمّحين إلى صعوبة أساليب التآليف غير التعليمية، وقد كانت الثروح إحدى الوسائل التي قام بها اللفويون لتقريب وتبسيط المادة العلمية مثلما فعل ابن مالك الني نظم النحو والصرف على مزدوج الرجز بما يقرب من ثلاثة آلاف بيت وسمّى هذه المنظومة بالكافية الثافية ثم شرح هذه المنظومة وسمتى الثرح بالوافية ثم اختصر هذه المنظومة إلى ألف بيت وسمّاها (الخلاصة) وهي المعروفة بالألفية ويرى الدكتور مهاي المخزومي أن نظم العلوم ووضع المقدمات والمتون كان طابع الدرس في العصور المتأخرة، وكان واضعوها يزعمون أنهم بهذا كانوا يتوخون التيسير للحفظ، وقد أحسنوا إذ لم يزعموا أنهم كانوا يتوخّون التيسير للفهم.24(24نعتقد أن الحفظ قرين الفهم لتلك المنظومات؛لأن الأقدمين ما وضعوها إلاً للغايتين معاً. ولو عدنا إلى المظان اللغوية لوجلنا أن من أوائل من نادى بالتيسير على طلاب العربية هو الجاحظ (ت التهيل 255 هـ إذ يقول: اوأمّا النحو فلا تثغل قلبه - أي الصبي - منه إلا بقدر ما يؤدّيه إلى السلامة من فاحش اللحن، ومن

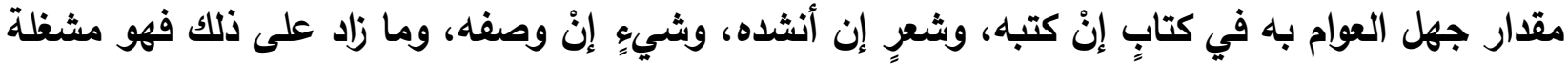
عمّا هو أولى به، ومذهل عما هو أردّ عليه منه من رواية المثل والثاهد، والخبر الصادق والتعبير

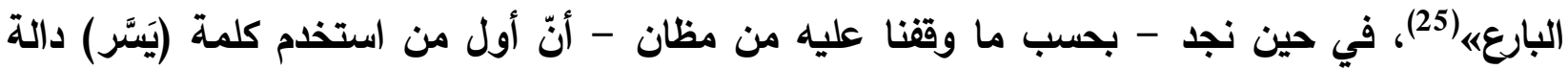

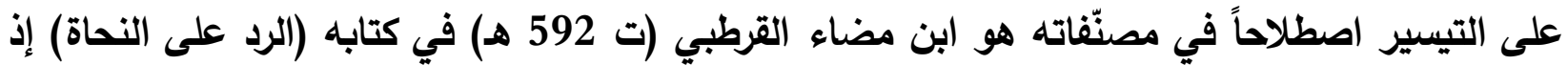
عُدَّ أول من دعا إلى التيسير والإصلاح من ناحية ومناقثة الأصول والمبادئ النظرية التي وضعتها مدرسة البصرة من ناحيةٍ أخرى، ونقدها على وفق أصول نظرية جديدة، وقد تأثر بدعوته هذه أصحاب التيسير

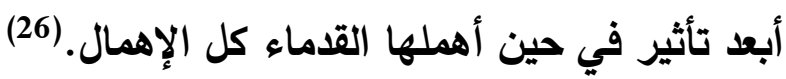
والنص الذي وردت فيه كلمة (يَسَّر) هو: لاوأنا أنصحمم لا للاقتناء ولا للاكتساب، ....، فبعضهم أثنى وشكر، وأتمر لما أمر، واستبدل بما يعر ويضر، ما ينفع لدى اللزبات ويَسَّر، وبعضهم تهاون بمقاله، واستمر على حاله..... هذا الكلام جزء من مقدمة ابن مضاء في كتابه (الرد على النحاة) وهو هنا يوجّه كلامه إلى النحويين ناصحاً لهح بالتخفيف والتسهيل على المتعلمين، وقد سبق هذا النص كلام له بَيَّن فيه سبب تأليفه للكتاب

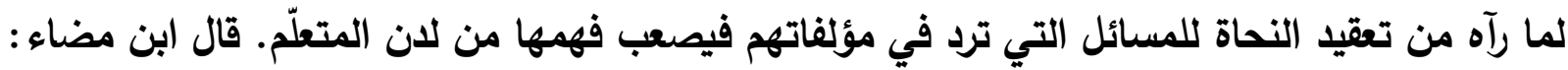


"اوإنّي رأيت النحويين - رحمة الله عليهم - قد وضعوا صناعة النحو لحفظ كلام العرب من اللحن،

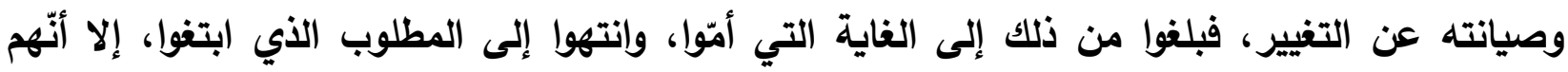

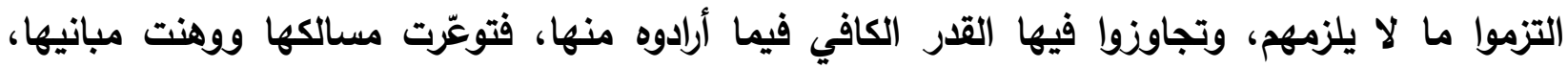
وإنحطت عن رتبة الإقتاع حججها، حتى قال شاعر فيها:

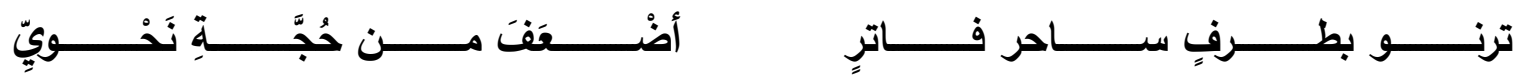
على أنها إذا أخذت المأخذ المبرأ من الفضول، المجرد عن المحاكاة وإلتييل، كانت من أوضح العلوم

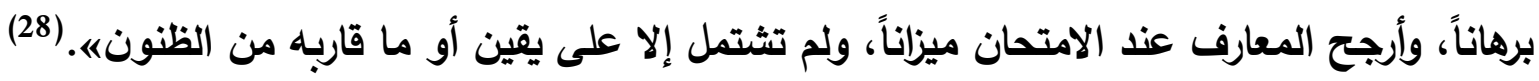
وكتاب ابن مضاء لم يكن خاصاً بالقضايا النحوية التي تناولها النحاة في مؤلفاتهم وكيفية تيسيرها، إلاتها، إنما تضمّن دعوة منه إلى تسهيل بعض القواعد الصرفية عبر إسقاط التمارين التعليمية التي ترهق فكر فئ

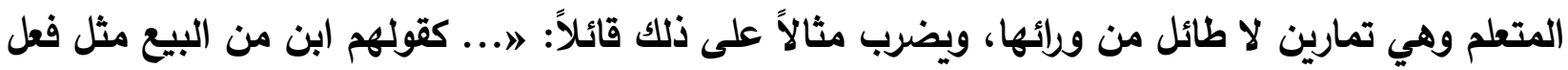

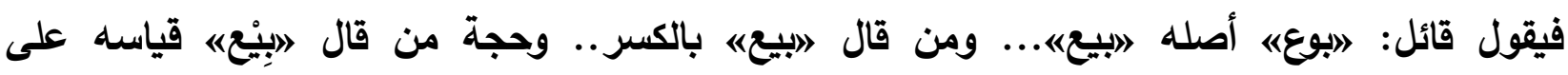

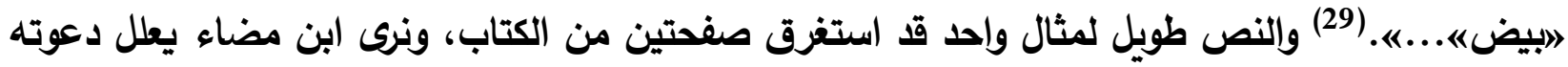

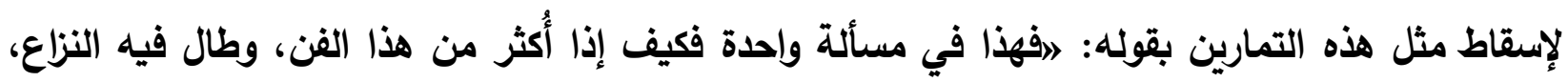

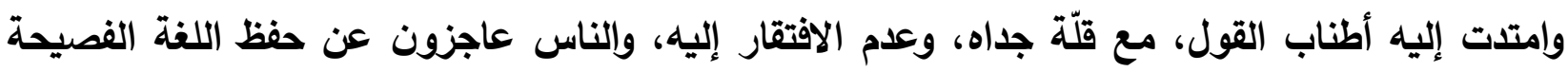
الصحيحة، فكيف بهذا المظنون المستغنى عنه!ه.(30) وتوالى المنهج العلمي ما بعد ابن مضاء القرطبي واستمر تأليف المختصرات والمتون اللغوية لشعور اللغويين بصعوبة المادة العلمية المؤلفة، فكان أن انصرفوا إلى وضع تلك المتون والمختصرات وهي تتفاوت في قيمتها العلمية من مصنف إلى آخر على أن الههف منها جميعاً هو التبسيط والتسهيل للمتعلم وإنْ

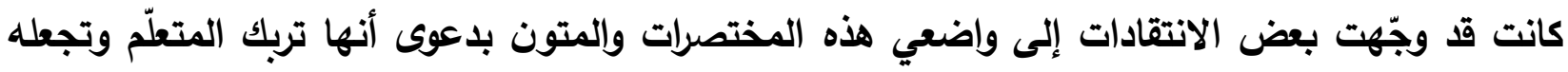

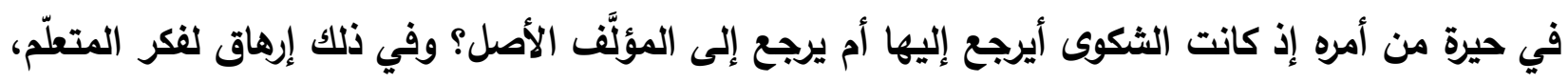
ومن الانتقادات التي وجهت إلى هذه المتون والمختصرات إنَّ اللغوي لم يعد قادراً على الإتيان بشيء إلى الثيء

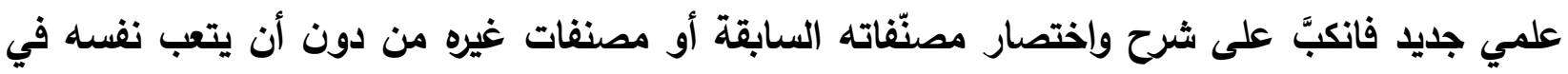
تأليف مصنَّف جديد فيه من المعلومات ما لم يتطرّق إليه هو ولا غيره سابقاً. ومع هذا كله لا يمكن أن

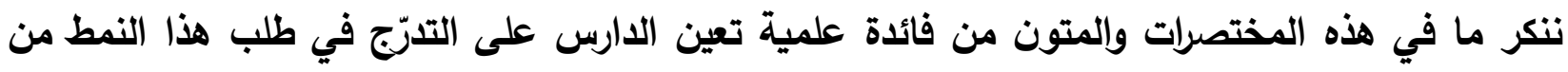

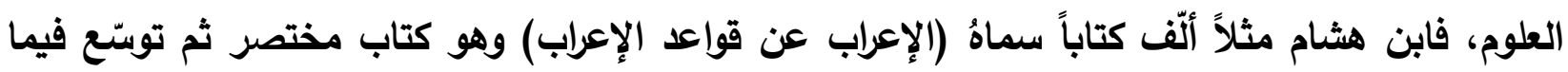

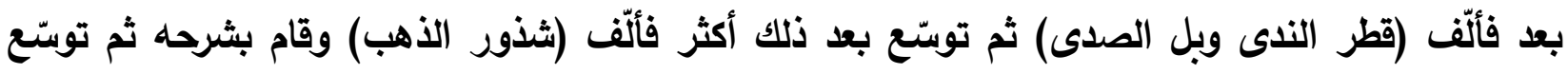
فألف (أوضح المسالك إلى ألفية (بن مالك) ثم ألّف كتابه (مغني اللبيب) بمنهج مبتكر، وكل هذا التدرج في 
التأليف لم يكن عشوائياً غير مدروس، بل كان يتماشى مع ذوق العصر وطبيعته والوقوف عند حاجة المتعلمين المبتائين والدارسين الباحثين ومدى إدراكهم وإستيعابهم للمادة العلمية. (31) ومن الدارسين من يُفرِقِ بين المتون التي شاعت وظهرت في القرن السابع الهجري والمختصرات التي ظهرت في ذلك العصر، إذ ذهب أحد الدارسين إلى أنّ المتون قد أخطأت الطريق إلى العلاج أو الإصلاح فبالغت في التكثيف والاختصار والإيجاز ولاسيما ما وقع منها في المنظومات بسبب قيود الوزن إنات

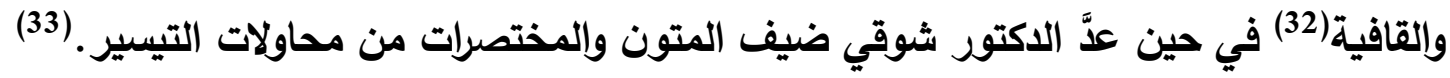
وقد اعترض الدكتور نعمة رحيم العزاوي على أبي الاكتور شوقي ضيف ولم يوافقه رأيه السابق قائلاً: اوكان عليه - أي الدكتور شوقي ضيف - أن يخرج المتون من بين محاولات التيسير، فالتيسير لا يكون بتصفية القواعد أو تقطيرها - على حد عبارته - في صيغ مجملة أشبه ما تكون بقوانين مركزة تستظهرها الناشئة فتستوعب أوضاع العربية ومقومات صياغتها بل إنّ المتون أضاعت أعمار عشرات من المؤلفين وهم يسعون وراء تركيز القاعدة في بيت أو جملة... كما أضاعت أعمار آلافٍ من الطلاب وهم يحاولون

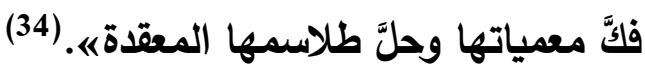
ولم يوافق أحد الباحثين(35) ما ذهب إليه الدكتور نعمة رحيم العزاوي ودافئافع عن وضع المتون والمختصرات وذهب هذا الباحث إلى أن هذا الوصف الذي أطلقه الاكتور العزاوي لا ينطبق على كل المتون والمختصرات، وعلّل دفاعه بأنّ غزارة التأليف اللغوي في المطولات والموسوعات والمختصرات والمتون والثروح تمنح الدارس والمتعلّم حرية اختيار الأسهل، وذكر بأنه ليست كل المتون غامضة وملغزّة يصعب

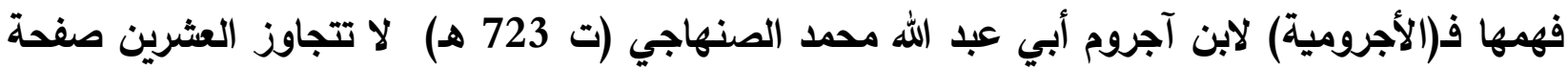
وقد نالت شهرة واسعة وذاع صيتها لأنها قدمت النحو العربي في أبواب متعددة مقتصرة على أبوابه الرئيسية، ولعلّ ما نالته من ذيوع وقبول يؤكدان أنها مع غيرها من المتون ليست جميعها تتصف بالغموض والتلغيز كما ذهب الاكتور العزاوي ومن قبله الدكتور عبد الوارث مبروك، فبعضها قّم المادة العلمية سهلة واضحة، فالرغبة في التيسير كانت قائمة عند هؤلاء المؤلفين. ويخلص الباحث حاتم حسين علي قائلاً: اإنَّ التيسير لا يقوم على الاختصار الثديد والحذف، وإنّما يكون في عرض الماده المادة اللغوية عرضاً سهلاً يقرِب الدرس اللغوي من غايته الأساسية التي كانت واضحة عند علماء العربية مثل الجاحظ وابن الأثير وغيرهما، وإذا كنا لا نستطيع أن نجرّد الثقافة العربية من التيارات التي شكّلت الأرضية المعرفية لتلك الحقبة المتمثلة بالمنطق والفلسفة وعلم الكلام فإنّ إيغال اللغويين في تحكيم تلك العناصر في التئ اللغة

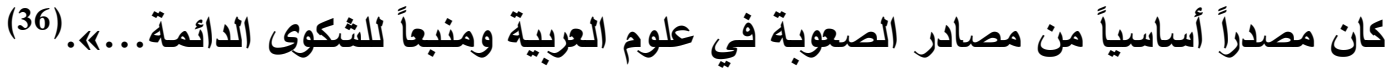

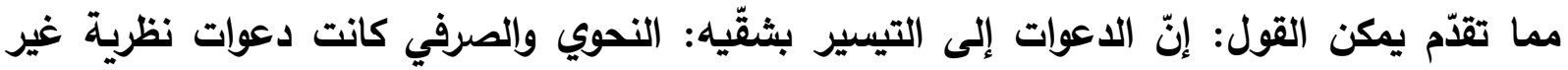


تطبيقية، أي لا تمسُّ القواعد والبنى وإلتراكيب بل اتخذت جانباً تعليميّاً واستمر هذا المنحى حتى العصر الحديث مع ابتداء عصر النهضة , ثم تطوّرت تلك الدعوات شيئاً فثيئاً، واستمر تأليف الكتب التعليمية المبسطة، ومع تطور الحياة المدنية وتشقب ميادين الحياة باتت الحاجة ملحّة لاستحداث صيغ وتعبيرات جديدة تلائم حاجات الناس، واختصار صيغ أخرى أو تغييرها بما يواكب العلوم والمعارف الوافدة، فأنشئت المجامع اللغوية لتراقب الأداء اللغوي في ظل الثورة الصناعية الهائلة، ومن تلك المجامع اللغوية (مجمع اللغة العربية بالقاهرة) الذي دعت أسباب كثيرة إلى إنثائه وقيامه نذكر منها: 1- ما يظهر من مشكلات بسبب ترجمة ونقل الكتب الأجنبية إلى اللفة العربية. (37)

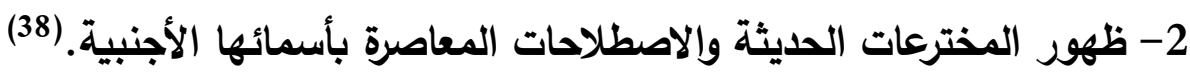

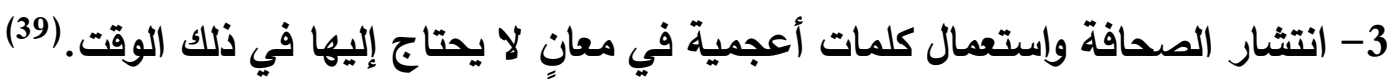
4- ظهور دعوات هادمة للفصحى كدعوة أمين شُميّل (ت 1315 هـ) وويلككس (ت 1351 هـ 135 هـ لهجر الفصحى وإحلال العامية محلها. (40) 5- قضية التعربب وما ينتج عنها. (41) 6- مواكبة ما يستجد من مخترعات وعلوم وفنون واصطلاحات. (42) ويستطيع الباحثان الوقوف عند قضية مهمة دعت إلى إنثاء وقيام مجمع اللغة العربية بالقاهرة وهو ظهور أنماط أدبية جديدة لم تستوعبها القوالب اللغوية المعهودة مما أضطر إلى تحفيز اللغة بغية الوصول للانزياحات اللغوية الميسرة الأمر الأي ترتب عليه خلق ضرورات لغوية على مستوى التركيب

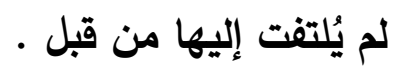
وقد كانت للمجمع أهداف وأغراض من أهمها أن يحافظ على سلامة اللغة العربية وأن يجعلها وافية بمطالب العلوم والفنون في تقدّمها ملائمة على العموم لحاجات الحياة في العصر الحاضر وله أن ينظر في

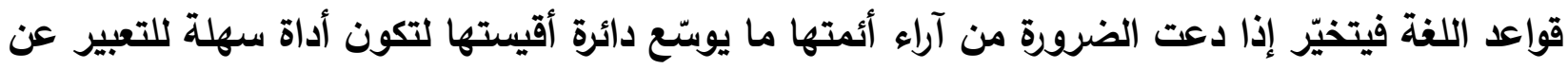
المقاصد العلمية وغير العلمية وأن يستبال بالكلمات العامية والأعجمية التي لم تعرّب غيرها من الألفاظ

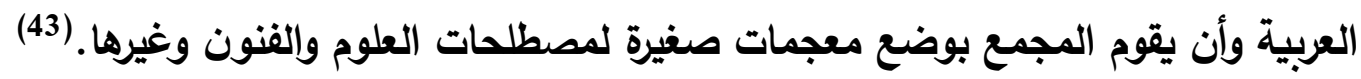

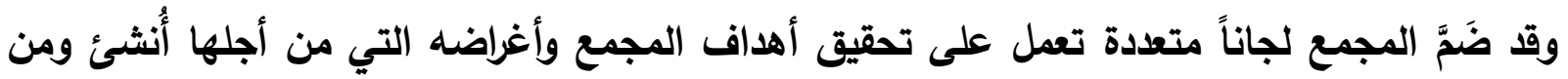
ضمن هذه اللجان (لجنة الأصول) التي تُعنى بتيسير الكتابة وتيسير قواعد النحو والصرف، وقد عملت هذه

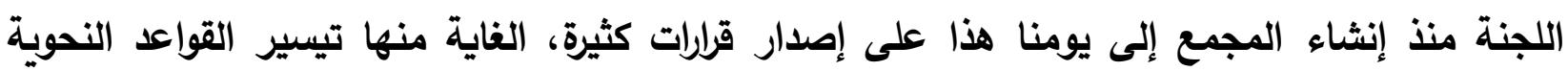
والصرفية بما يلائم متطلبات العصر، والملاحظ أن القرارات التي أصدرها المجمع فيما يتعلّق بالقضايا

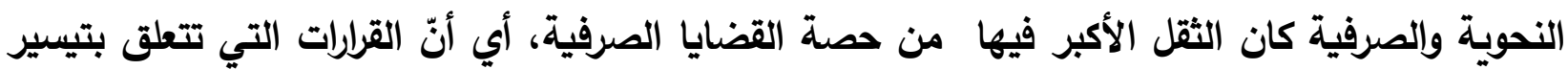


الجوانب الصرفية في اللغة العربية لقيت عناية من لان المجمع أكثر من العناية بما يتعلق بتيسير القواعد

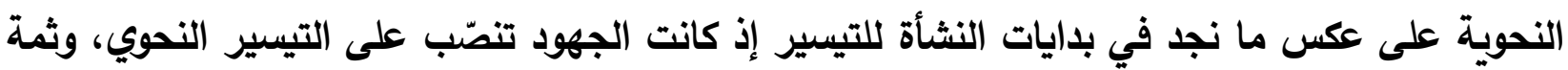
بعض الاهتمام بالتيسير الصرفي، ويمكن تعليل ذلك بأنّ النحو قائم على تراكيب وجمل وعلل، فكانت الحاجة تستدعي التبسّط في هذه التراكيب والجمل، أما في العصر الحاضر وبسبب التطور المدني والحضاري والحاجة إلى وضع مصطلحات فقد استدعى ذلك الاهتمام بالجوانب الصرفية، لأنّ الصرف يتعامل مع مفردات وصيغ وإثتقاقات، فلا غرابة بعد هذا أن نجد قرارات المجمع الصرفية أكثر من قراراته النحوية، مع عدم إهمال القضايا النحوية والالتفات إليها، ولكنّ الحاجة تستدعي إصدار قرارات صرفية أكثر مرك من النحوية. إنّ جُلّ ما قام به المجمع من أعمال وإصدار قرارات يعدُ خطوة على طريق التيسير سواء الصرفي أم

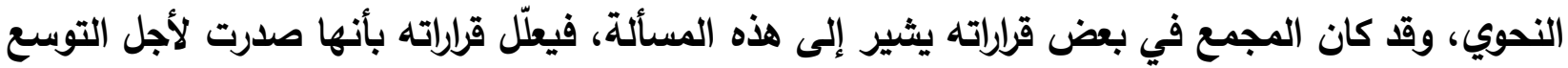

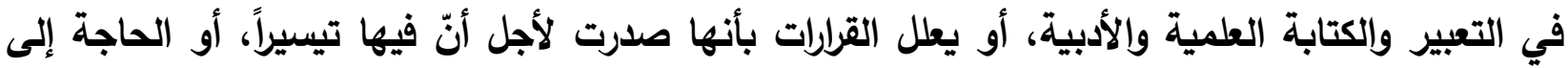

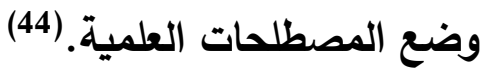
وقد كان لقرارات المجمع أثر فعال في حل كثير من المشكلات اللغوية التي واجهت الباحثين المختصين وغير المختصين، وقد كانت هذه القرارات موضع ترحيب وإتحسان من الجميع، إذ احتج بها كثير من المختصين وأثشادوا بها وجعلوها حجة في مؤلفاتهم، فقرار المصدر الصناعي مثلاً كان من أكثر القرارات

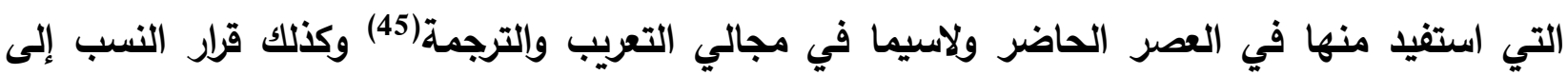

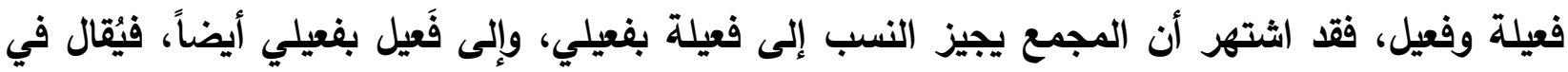

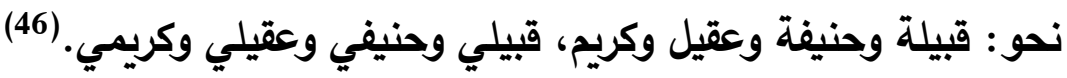


مسوّغات التيسير وغاياته

لم ينشأ التيسير اللغوي لأجل ترفٍ فكري بل كان حاجة فرضتها متطلبات المرحلة، وشأنه شأن أي

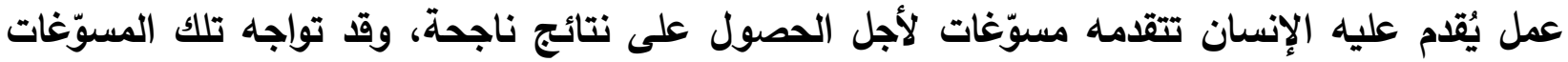
بالرفض أو القبول وتُقدم للرفض أسباب وتقدم للقبول أسباب أيضاً. فكذلك (التيسير اللغوي) كان لظهوره

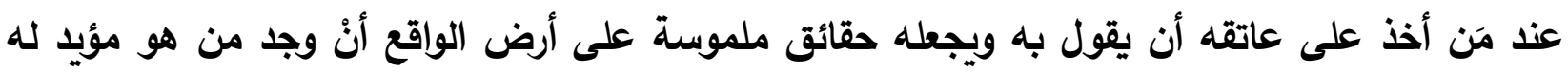

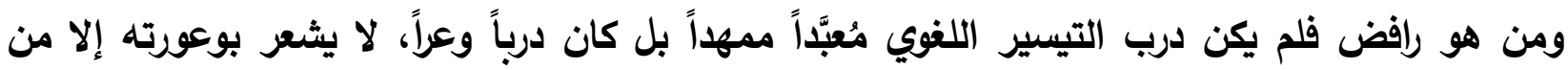
سلكه لتحقيق غايته.

على أننا في هذه العجالة لن نستطيع استقصاء جميع الآراء التي تناولت (التيسير اللفوي) رفضاً أو

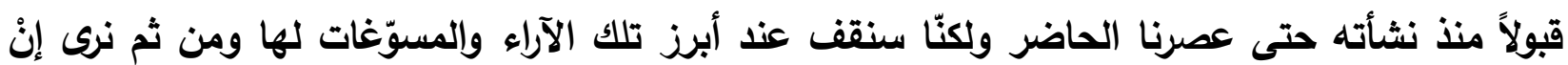
كانت تلك المسوّغات لكلا الطرفين مقبولة أم لا! نقول: إن استعراض مسيرة (التيسير اللغوي) بدءاً من محاولة خلف الأحمر التي أشرنا إليها في المبحث السابق وحتى الوصول إلى محاولة ابن مضاء القرطبي يظهر أن كل الدعوات إلى التيسير وما ألف لغرض التيسير من لان اللغويين الأوائل لا تعدو مجرد محاولات في التيسير التعليمي ومن ثََّّ ظهرت

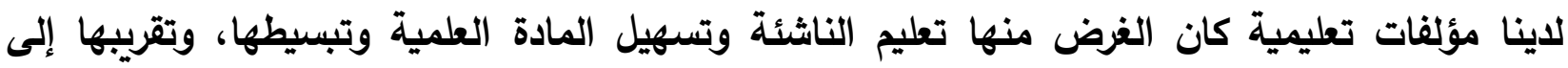
أذهانهم، أي أنّ المسوغ الذي سَوَّغ به أصحاب تلك الدانهات الدوات والمؤلفات عملهم هو التسهيل وإلتبسط بعيداً عن التعقيد والتوعز في المادة العلمية. قد يكون هذا أهم ملامح التيسير اللغوي في هذه المرحلة ولكن

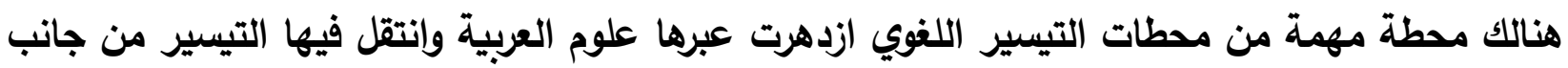
التيسير النظري (إن صحَّ التعبير) إلى جانب التيسير التطبيقي (إن جاز لنا أن نسميه بهذا الاسم) ونعني

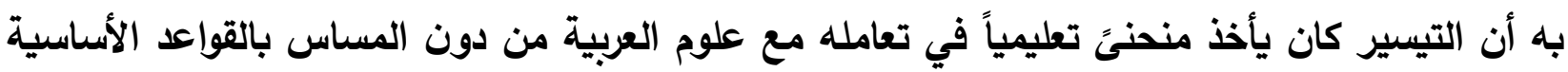

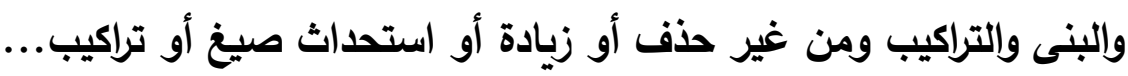

فانتقل في هذه المرحلة إلى طور الاستحداث والابتكار والإضافات، ويمكن تعليل هذا التطور باتصال العربية بالحضارات الأجنبية في العصر العباسي وما بعده، والتأثر بالتيارات الفكرية بعد القرن الثالث للهجرة، يتحدث د.شوقي ضيف عن هذه المرحلة قائلاً:(( وظلت للعربية في العصر العباسي وما بالتيات بعده مقوماتها ومن هذه المقومات أنها تعد من أغنى اللغات بمفرداتها وساعدها في ذلك من قديم الزمان كثرة 
اثتقاقاتها وكثرة أبنيتها وميل أهلها إلى التخصيص وابتكار الكلمات الدالة على أدق الدقائق على الأثشياء، وكذلك ما اتسّمت به من مرونة وقدرة على الوفاء بالإفصاح عن كل ما يتصل بالتعبير عن الحضارات

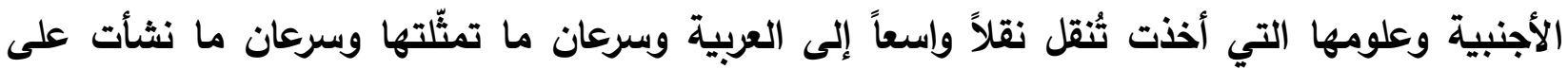

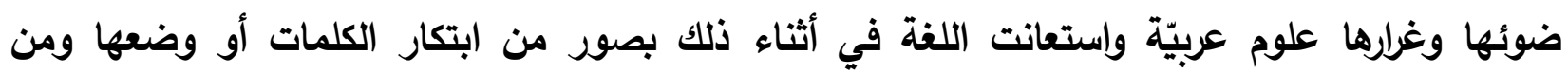

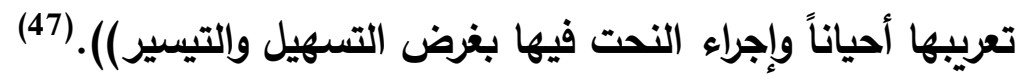

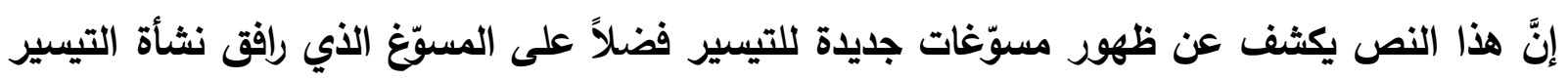

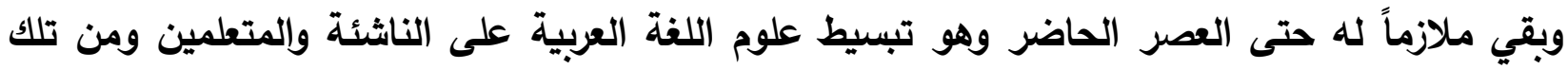
المسوّغات التي يمكن عبر استقراء النص التوقف عندها هو التطور الحضاري الحاصل آنذاك من خلال اتصال الثقافة العربية بغيرها من الثقافات مما يستدعي الإفادة من مصطلحات تلك الحضارات عن طريق تعريبها وجعلها شائعة مستعملة في اللغة العربية وكذلك استحداث كلمات جديده تواكب ذاتك التطور

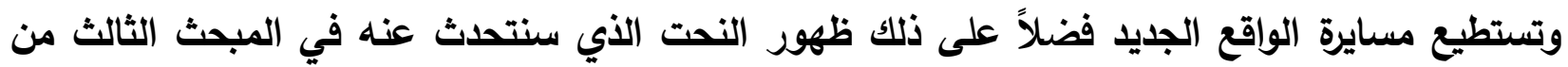
بثنا هذا. إنَّ كلَّ ما طرأ من تغييرات على واقع اللغة العربية كان الغرض منه التيسير والتسهيل على أن يكون ذلك خاضعاً لقواعد العربية ولا يمسُ أصولها وليس فئ فيه خروج أو أو شذوذ عما وضعه اللغويون الأوائل. والمحطة الثانية من محطات التيسير المهمة كنت متمثّلة بالصرخة المدوية التي أطلقها ابن مضاء التهاء القرطبي (ت 592 هـ) من خلال كتابه (الرد على النحاة) الذي تضمّن دعوة إلى إعادة النظر في الأصول

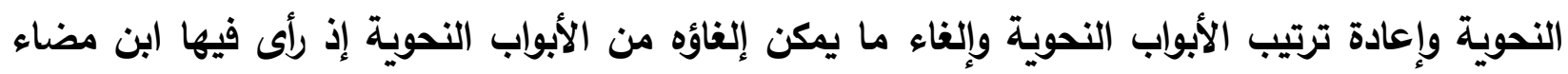

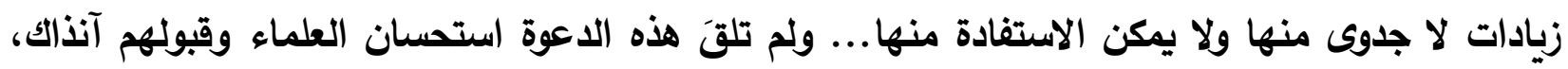

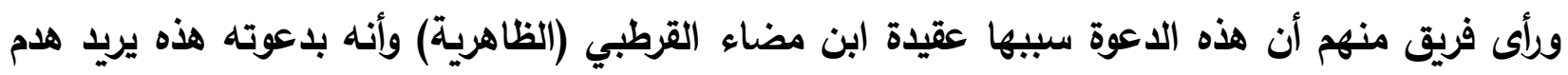

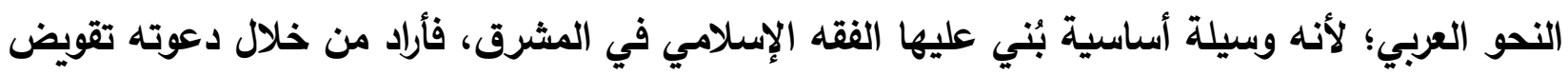

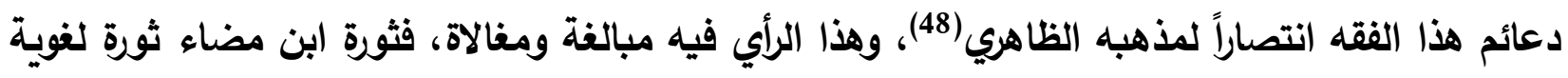
نحوية وليست ثورة مذهبية، والفقه الإسلامي واحد وإن تعددت واختلفت مذاهبه، وإذا كان الملاحظ وجود

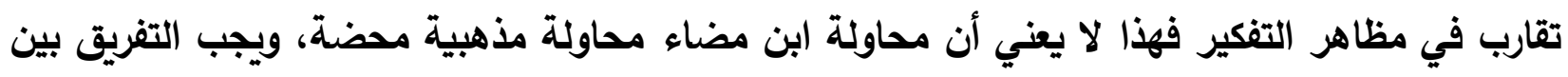

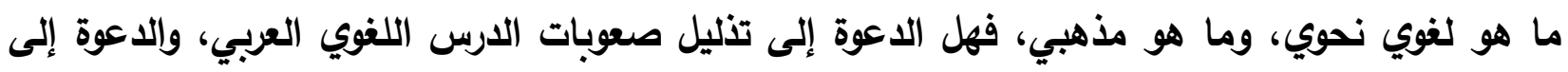

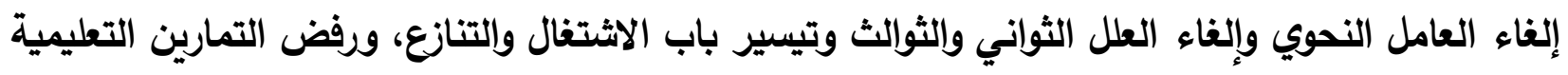

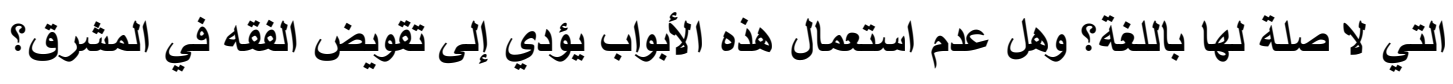

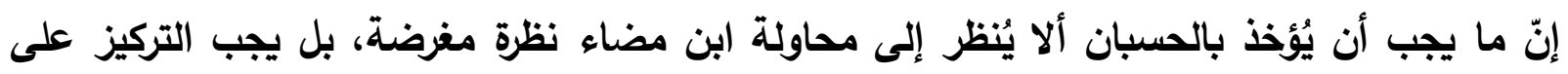


جوانبها اللغوية، فهي ليست مفروضة على أحد (49). ممّا تقدم يمكن عدّ ابن مضاء القرطبي صاحب أجرأ محاولة إصلاحية في تاريخ الدرس اللغوي العربي، فئه فهو لم يكتف بعمله النظري في النحو، بل شفعه بعمل تطبيقي وضع فيه نظريته موضع التنفيذ فقد ذكرت

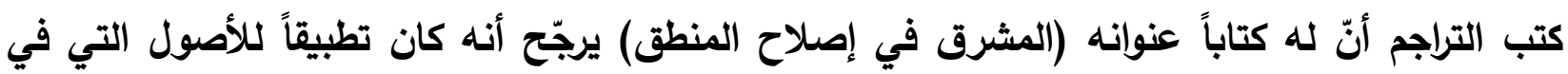
كتابه (الرد على النحاة). (50) لقد خلّصت نظرية ابن مضاء النحو العربي من كثير مما علق به من شوائب التأويل والتقدير والتعليل،

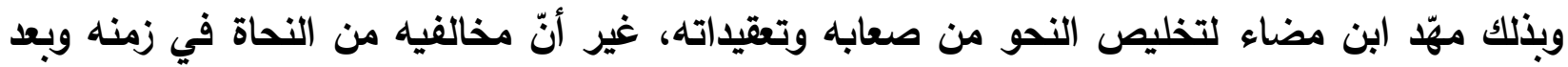
زمنه صمّوا آذانهم عن دعوته، وظلوا يؤلفون مظولاتهم الضخمة حاملة ما لا يُحصى من مسائله العويصة فئه وعقده العسرة. (51) ويبدو أنّ الإهمال الذي واجهته ثورة ابن مضاء كان بسبب العصر الذي سادته ظروف سياسية وفكرية

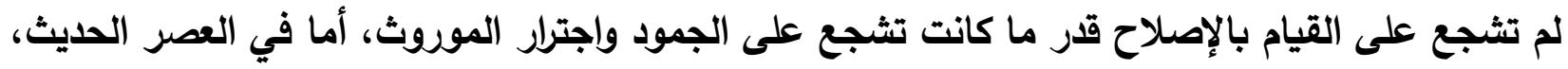
فقد بعثت نظرية ابن مضاء، وأسهمت في تغذية محاولات التجديد وإلتيسير التي قامت استجابة لروح (52) (52). (15).

لم تهمل العصور المتأخرة نظرية ابن مضاء في تجديد النحو وتيسيره فحسب، بل أهملت الإلتماعات التيسيرية التي انبثت في التراث، لأنَّ هذه العصور لم تنجب نحاة تهيئهم قدراتهم العقلية للانتفاع بما

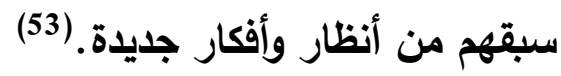
على أية حال، فحاولة ابن مضاء القرطبي قد فتحت الباب أمام الدارسين المحثثين للوقوف عندها، وكان لها كثير من مؤيديها في الوقت الحاضر، ومن ضمنهم أعضاء في مجمع اللغة العربية بالقاهرة، الذين دعوا إلى إحيائها - على العكس من العلماء القدامى الذين دعوا إلى إغلاق الباب بوجهها - وابن

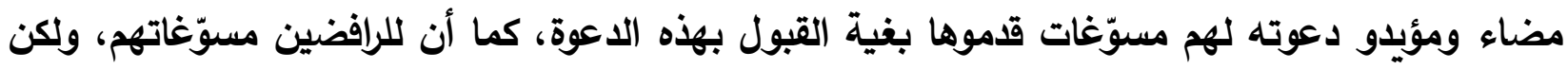

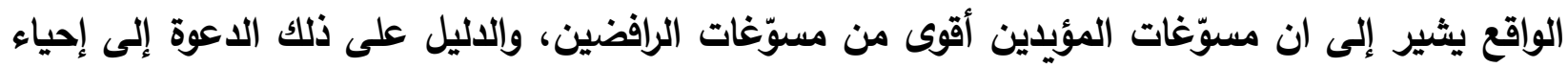
هذه المحاولة والتمسك بها بدعوى أن فيها تيسيراً وتبسيطاً لعلوم العربية. ونحاول أن نختصر المسافات ونظوي صفحات من الزمن لنصل إلى العصر الحديث ونلتقط بعضاً من مسوّغات القبول بالتيسير عند المحدثين وبالمقابل مسوّغات الرفض للتيسير عند غيرهم. إليك نص أحد العلماء المحدثين وهو يتحدّث عن التيسير قائلاً: ״فما زال الناس يفضّلون السهل، ويتّبعون اليسير حتى أصبح ذلك عندهم عادةً لا يقدرون على

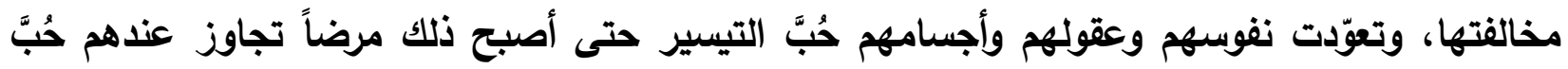


التيسير من الأمور المعاثية، ووسائل الحياة المادية، إلا ما لا يجوز التهاون فيه من أمور العقل ووسائل

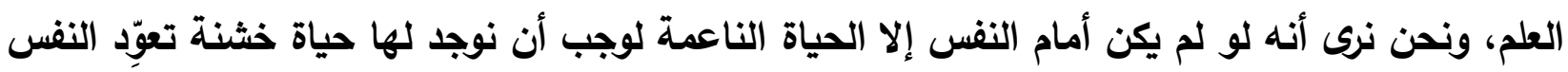

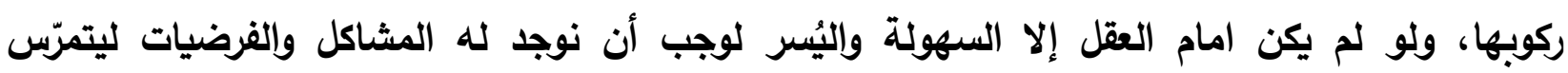
بالصعب ويقوى على العسير، وما نظنٌ أنَّ القدماء من العلماء كانوا يكثرون على طلابهم من الأمور

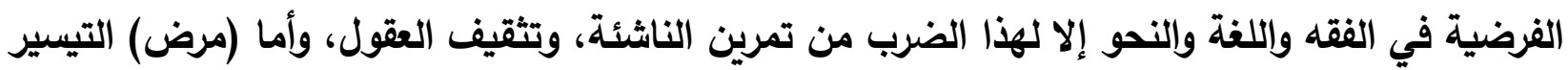
اليوم فقد استشرى وتجاوز كُلَّ حد، وأصبحنا نرى العلماء يتنادون ويعقدون المؤتمرات لتسهيل الإملاء أو تطوير النحو أو تيسير العربية.. تماماً كما يتنادى زملاؤهم ويتكاتفون لتطوير وسائل النقل وأدوات الرفاهـ.. هؤلاء يتنافسون في الوصول إلى القمر والمريخ ومسابقة الصوت وأولئك يجهدون أنفسهم لحشو حقائق

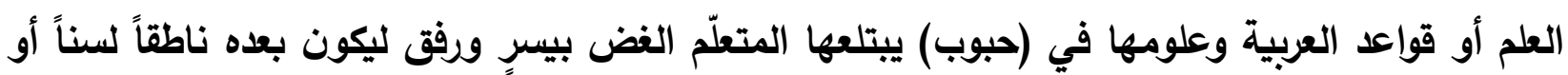

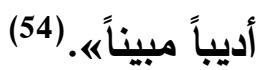

إنّ هذا النص قدّم قائله مسوّغاً رأى فيه أن المجتمع تماهى مع متطلبات التيسير في الحياة كلها ومن ضمنها التيسير اللغوي ولكنتا نقول: إنه حينما يتحدّث عن الذين ينادون بالتيسير اللغوي ويقارنهم بمن ييسّر وسائل الحياة المترفة ومتطلبات التطور المدني والحضاري عادّاً من يقوم بالخطوة الثانية أفضل ممّن

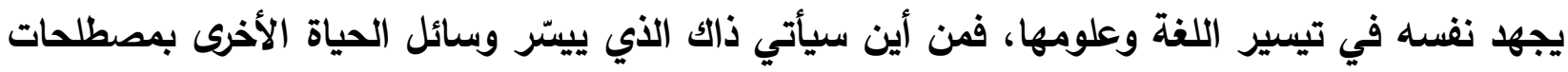

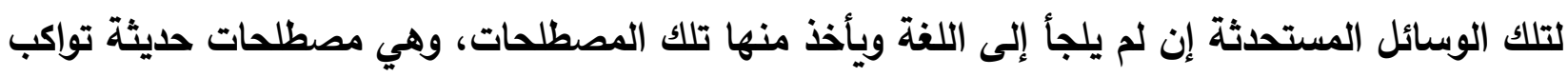

مستجدات العصر؟!

ولا تجد إحدى الباحثات جدوى من التيسير التعليمي للصرف قائلة: اإن هناك ثلاثة اتجاهات للباحثين المحدثين العرب لدراسة الصرف العربي القديم، وعُني الاتجاه الأول في الاراسات الصرفية التيسيرية التعليمية، وكان له بُعدان أحدهما تعليمي والآخر نظري، ولم يقدم هذا لهان

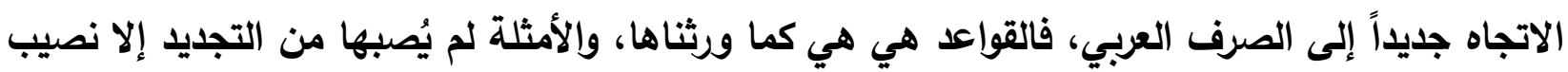
ضئيل، إذ اقتصر الباحثون في هذا الاتجاه على اختصار القواعد والثروح والتعليقات وحذفها، واستعمال الأسلوب السهل البسيط، وهذا ليس تيسيراً بالمعنى العلمي الدقيق، إذ إنّ التيسير يكون بعرض جديد للموضوعات الصرفية القديمة، كما أنّ محاولات التيسير تلك تجاوزت وصفير باليف اللغة إلى مسّ حقائقها

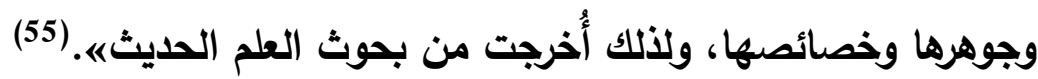

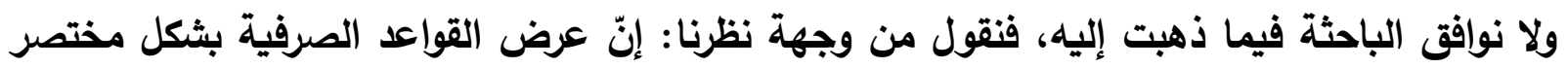

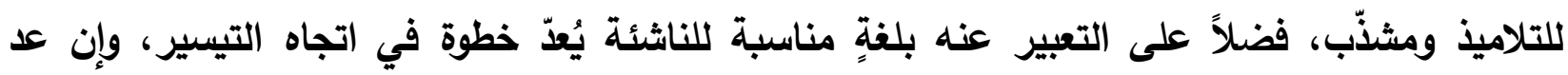
الباحثة هذا المنهج بعيداً عن التيسير العلمي الدقيق للصرف، كلام فيه نظر لأن المجامع العلمية اعتمدت فئه اتجاه 
الإضافة كما اعتمدت الحذف، ولأنّ كل التيسير يقوم على الحذف والاختصار والاستحداث والإضافة، وبعد هذا نقول: ليس من العدالة والإنصاف أن نبخس حق القدماء في عملهم الذي أرادوا من خلاله التيسير بثقيه: النحوي والصرفي، وإن اختلفت طرقهم في الوصول إلى هذه الغاية، وعلى رأس هؤلاء القدماء يقف هن هن ابن مضاء القرطبي، الذي ما تزال دعوته تملأ آفاق البحث اللغوي حتى يومنا الونا هذا. "اولقد جرت محاولات كثيرة في القديم والحديث للنظر في قواعد العربية بهدف تيسيرها وتقريبها من

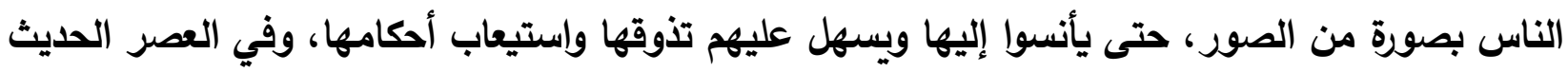
تزاحم (المصلحون أو مَن يدّعون الإصلاح) حول هذه القضية وتسابقوا في الهجوم على القواعد الموروثة لاضطرابها وتخلّفها عن روح العصر، وصعوبة إيفائها بحاجات التعبير بالأساليب الحديثة وجدّوا واجتهدوا والقوا إلينا بأعمال كثيرة تنثد ما سمّوه (إصلاح النحو) وحملت أعمالهم هذه أسماء وعناوين تنبئ عن هذه الفكرة (الإصلاحية) مثل: (تهذيب النحو - تحرير النحو - تيسير القواعد - النحو الواضح - النحو المصفّى...) والملاحظ على كل حال أنّ هذه الأعمال في جملتها لم تنجُ من القصور في الوفاء بآمال

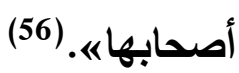
هذا النص يحمل في طياته دعوة إلى التيسير، ولكن ليس على حساب القواعد الموروثة الأصيلة للغة، فالتيسير يجب أن يواكب متطلبات العصر الحديثة ومستجداته مع الحفاظ على الأصل اللغوي، ويبيّن هذاب

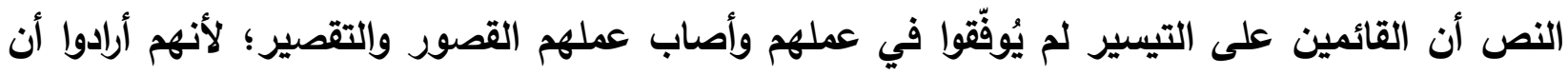

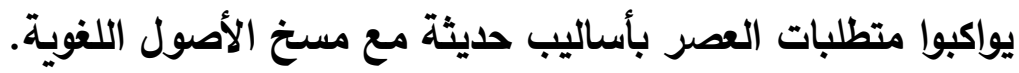

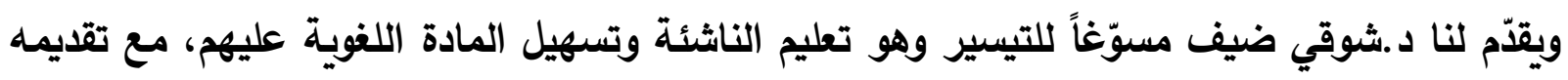

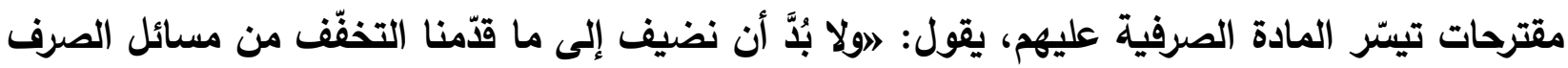
العوبصة التي لا تفيد الناشئة في صحة النطق بالعربية بل لا بُّّ من حذفها كمسائل الإعلال ومثلها مسائل

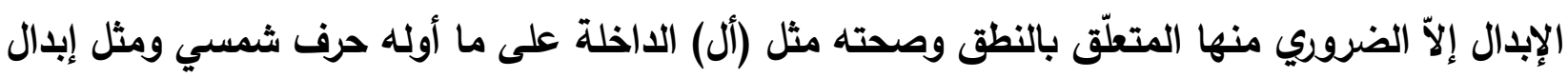

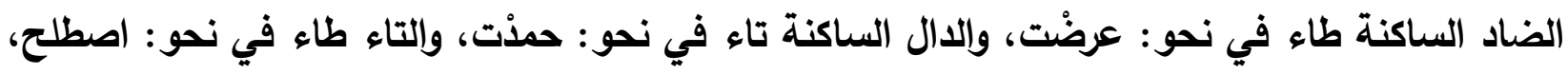
وينبغي التخفّف في دراسة التصغير فلا يُدرّس للناشئة منه إلا الثلاثي والرباعي، دون التعرض لما لاء لا

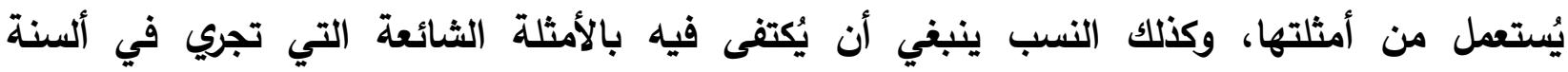
الناشئةهـ. (57)

\section{ويضيف قائلاً:}

الاوممّا ينبفي التخفّف منه في القواعد المتراكمة في بعض الأبواب الاكتفاء بعرض صيغٍ وأمثلة كثيرة في

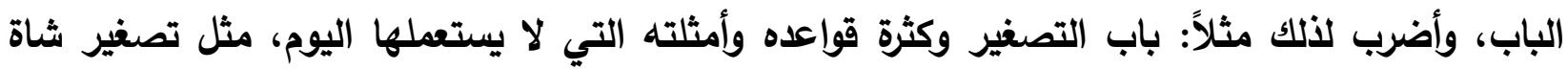




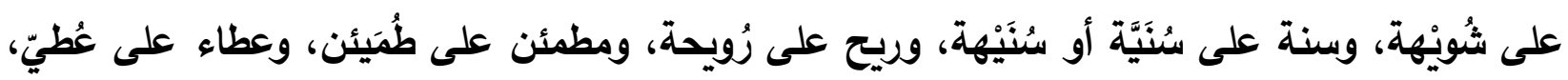

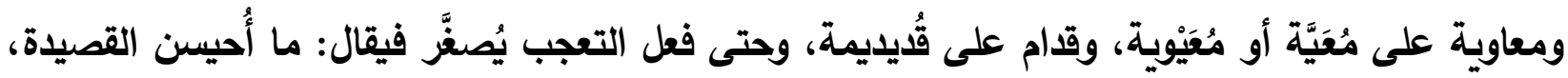

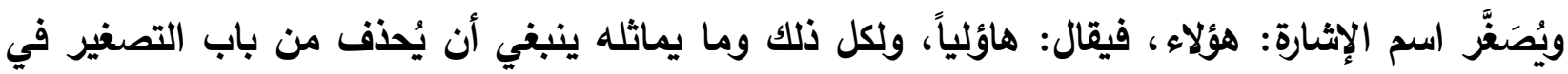
كتب النحو التعليمي، وتُذكر فيه فقط صيغه المستخدمة الائرة على الألسنة، وفي الكتب الأدبية مثل فئل

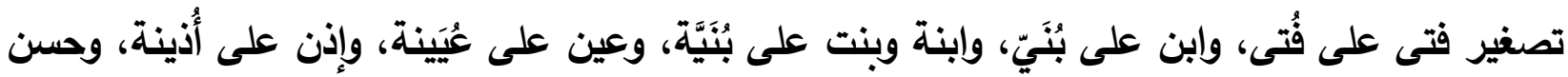

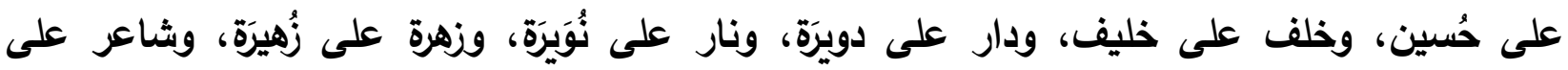

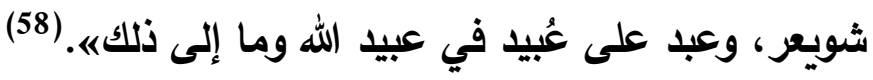
إن تيسير المادة اللغوية على الناشئة كان من أهم المسوّغات التي قدّمها علماء اللغة - القدامى

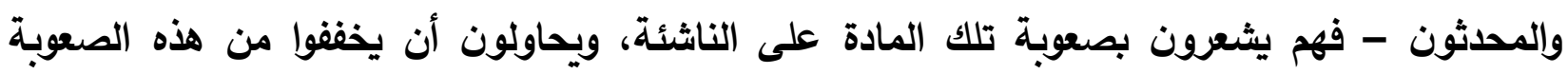
بثتى الطرق، وفي هذا أيضاً يقول د.إبراهيم السامرائي: "إنَّ العلم اللغوي الحديث يقتضينا وصف الظواهر اللغوية والنحوية، وهذا المنهج يفرض علينا طرح مناهج البحث القديمة، وبذلك يتم لنا ما نرومه من التيسير الذي أمسى ضرورة لتعليم لغتنا إلى أحداثنا،

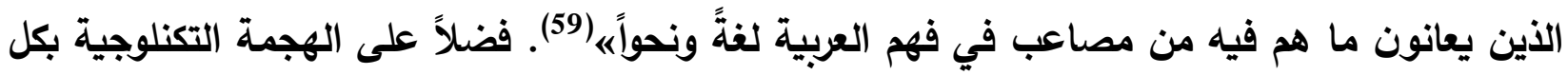
معطياتها التقنية والاصطلاحية التي تستلزم كثيراً من الجها في الترجمة والاصطلاح الميَّرّ على ألسنة الثباب والفتية الذين لا يدركون خطورة تجاهل استعمال المقابل العربي لكل تلك المعطيات. على أنّ هذه الدعوات للتيسير يجب أن لا تكون عشوائية بلا ضوابط، فيجب المحافظة لإنس على الأصول

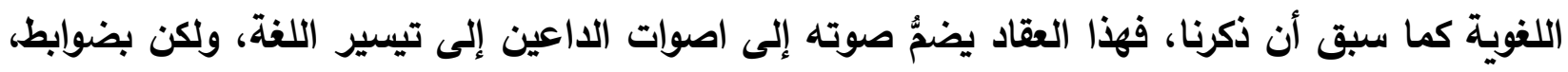

امن علامات الانحراف البعيدة عن الوجهة أن يحسب المجدّدون أنهم ينتهون يوماً إلى لغةٍ خالية من القواعد والأصول أو أن تُفَّر حملة التيسير هذه على أنها دعوة لانسلاخ اللغة من قواعدها، فالفرق واضح بين التيسير والتهايم الذي يدعو إليه مَن لا يرى في قواعد اللغة العربية ونحوها إلا عبئاً في سبيل الانطلاق الفكري والإبداع اللغويش. فالنص قد قيّ التيسير بثرط أن لا يخرج عن أصول العربية ومتعارف الكلام القديم.

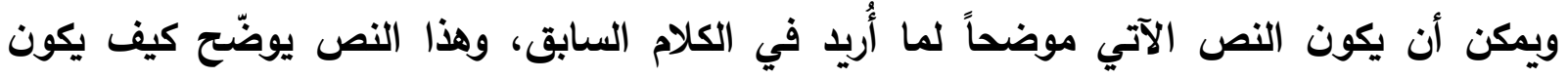
التيسير على وفق الضوابط، وهذا ما عمل به مجمع اللغة العربية بالقاهرة في مراحل تيسير اللغة العربية، ففي الحديث عن كيفية صوغ المصطلح العلمي يرى الاكتور محمد حسن عبد العزيز عضو مجمع اللغة العربية بالقاهرة أنّ أهميّة المصطلح العلمي تتأتّى من كونه لغة المنهج العلمي التي يتداولها العلماء ؛ 
لأنها تختزل كثيراً من المفاهيم على نحوِ مضغوط يؤدي الحقائق العلمية أداءً صادقاً , غير أن العلماء قد

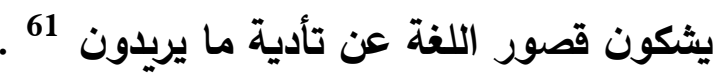
والحق أن لا قصور في اللغة , وإنما القصور يتأتى من عدم الإحاطة بأسرار اللغة وفنونها وحيثياتها على نحوٍ يسعفنا في إظهار المقابل ذي القدرة على احتضان المحتوى العلمي والوظيفي للوافد التقني الجديد فضلاً على توفير الحاضن اللغوي الملائم لذوق اللسان العربي في تلك اللحظة التأريخية التي يتطلب فيها وضع المقابل العربي لكل ما يفد على ساحة الاستعمال اللساني من تقنيات حضارية أو أساليب لغوية وحقائق علمية.

ولذلك فقد أخذ مجمع اللغة العربية بالقاهرة على عاتقه الملاءمة بين متطلبات العلم ومتطلبات العصر

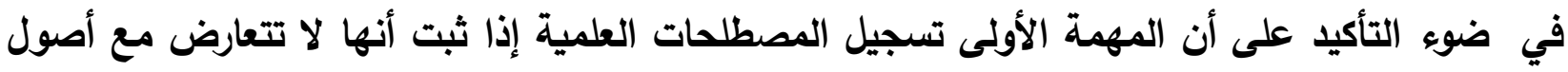
اللغة , وهذا ما يذكِّرنا بقاعدةٍ من قواعد قبول القراءة القرآنية إذا وإفقت العربية ولو بوجهٍ واحد ، فإذا كانت تلك الفسحة سجّلها الدرس اللغوي في تثبيت ما يتعلّق بأقدس نصٍّ لغوي تترتبّ عليه قراءة الثربعة

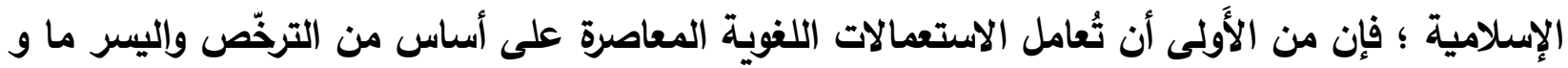
جدا إلى موافقة الأصول سبيلا. إن هذا النص يكثف عن أنّ ضوابط اللغة وقواعدها ليست قدسية، ولكن لا بل من وجود ضوابط عند

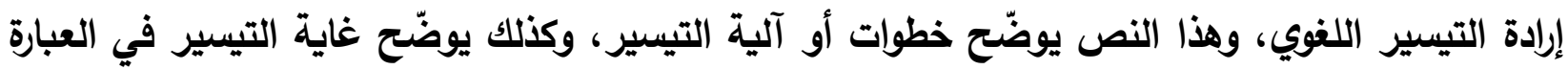
القائلة: 》بطريقة ميسّرة وبدلالة دقيقة محكمةه. ونلمح هنا بعض مسوّاتغات التيسير عند مجمع اللغة

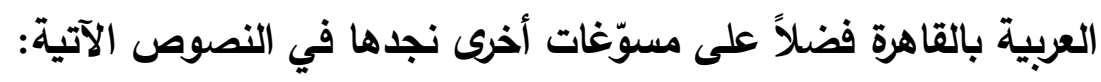

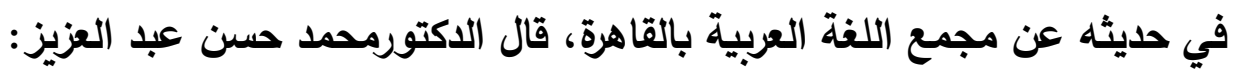
اإن المجمع ثمرة من ثمار النهضة العربية الحديثة، وتلبية لحاجةٍ شعرت بها الأمة العربية لكي تكون لغتها الفصحى وافية بمتطلبات الحياة المعاصرة، وملائمة لمقتضيات الآداب والعلوم والفنون، ولقد حرص المجمع منذ إنثائه على تحقيق هدفه في أن يحافظ على سلامة اللغة العربية، وأن يجعلها وافية لمطالب البهاب العلوم والفنون في تقدّمها وملائمة لحاجات الحياة في العصر الحاضر وتنوّعت وسائله إلى تحقيق هذا الههف ومن تلك الوسائل: تيسير اللغة متناً وقواعد وكتابة ورسم حروف، وتوفير المصطلحات العلمية والألفاظ الحضارية وتهذيب المعجمات اللغوية ووضع معجم تاريخي شامل وتثجيع الانتاج الأدبي وإحياء التراث القديم في اللغة والأدبه.(62) وقد دافع د. إبراهيم مدكور الأمين العام للمجمع عن القرارات التي أصدرها المجمع بغية تيسير علوم

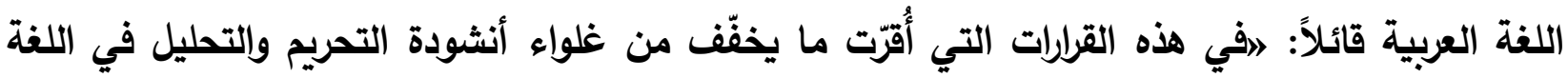


وما ييسّر على الكتّاب ويحميهم من بطش مَن ينادون بما يصح وما لا يصح وما يقال وما لا يقال وأصبح

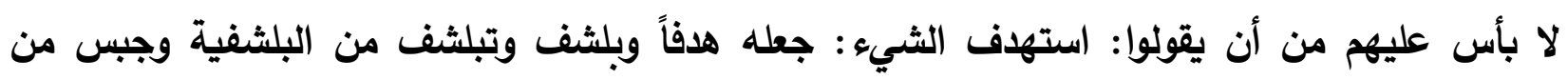

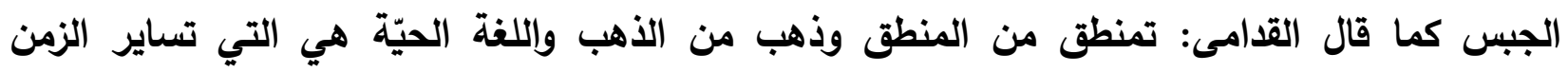
وتتمشّى مع كل جديده (63).

ويحاول أحد الباحثين المحثين أن يقلّل من أهمية عمل مجمع اللغة العربية بالقاهرة قائلاً: ارولا يلزمنا

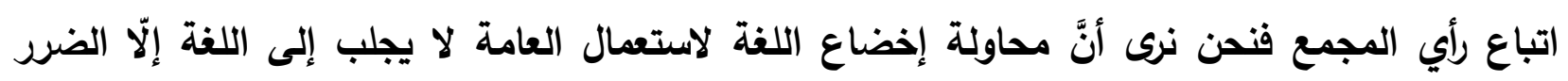
والخطأه (64). ونحن نقول للباحث: نعم نحن معك في ردك على مَنْ يجعل التيسير في العببية من دون ضابط فمن فئن

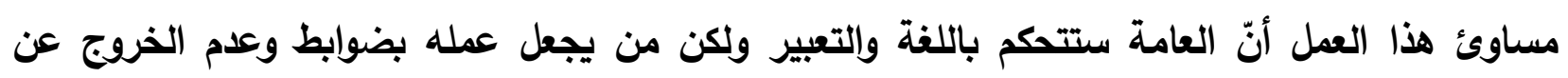

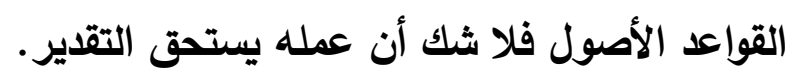

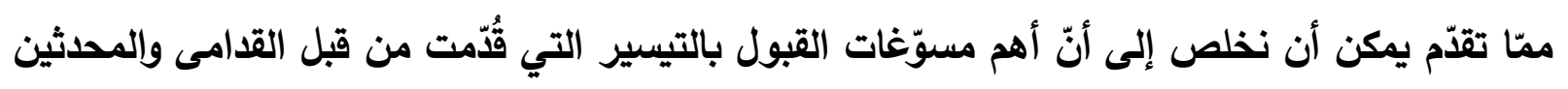

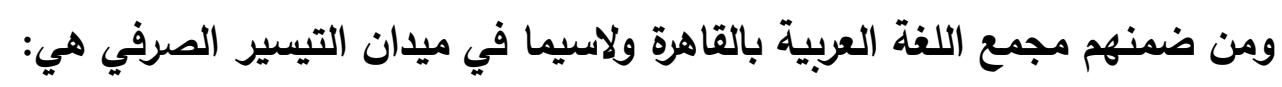
1. الحاجة إلى تيسير الصرف للطلبة وإلناشئين.

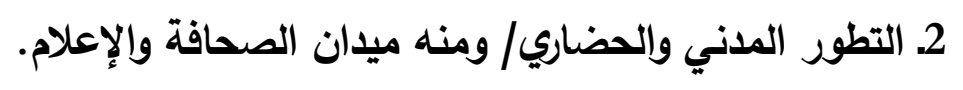
3. ت كثرة المصطلحات العلمية.

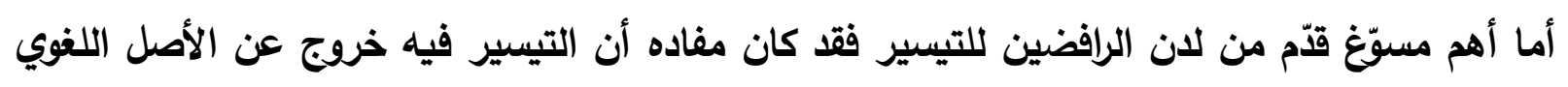

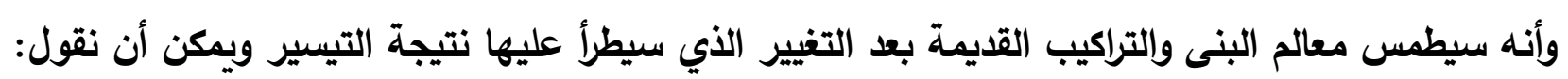

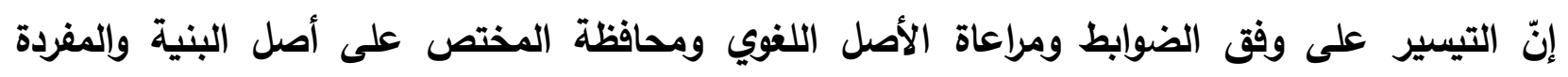
سيمنعان مثل هذا الطمس أو الإضرار بالأصل اللغوي. 
محور الأول المؤتمر اللغة العربية

المؤتمر العلمي الرابع لكلية التربية / جامعة واسط 


\section{أُسُ التيسير الصرفي \\ وأنماطه في قرارات المجمع}

للعرب ثوابت في صياغة القواعد اللغويّة نحويةً كانت أم صرفيّةً ومن أهم هذه الثوابت القياس ممّا عملت به مدرسة البصرة (المنهج المعياري حديثاً),والاعتداد بالمسموع ممّا أقزّته مدرسة الكوفة (المنهج الوصفي حديثاً), والالتفات إلى ما ييسّر على المتكلمين وإلدارسين استعمال اللغة بصيغها المختلفة. وقد زخرت كثير من الداسات بهذه الأسس اللغوية، وهذه الأسس اعتمدها مجمع اللغة العربية بالقاهرة

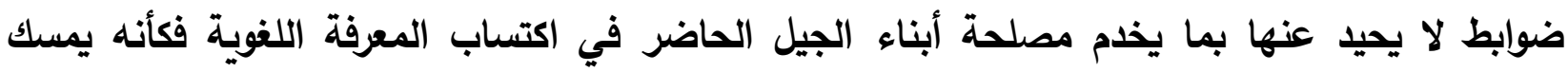
العصا من الوسط: يحافظ على الأصول اللغوية القديمة من جانب، وييسّر على الدارسين المعاصرين

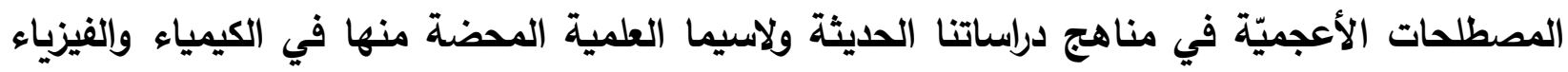
والطب وإلفلك وعلوم الحياة وغير ذلك من جانب آخر . ودونك الأسس التي قامت عليها قرارات مجمع اللغة العربية بالقاهرة بثيء من التهئ التفيل:

أولاً: الاعتماد على القياس:

يكاد يكون القياس هو الصفة البارزة في قرارات المجمع، ومن تلك القرارات التصريفية التي ذهب فيها

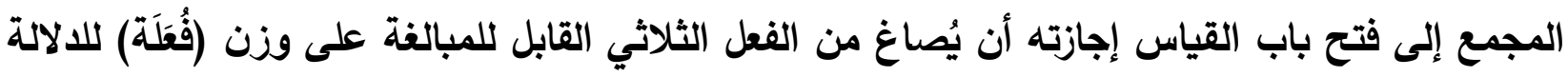

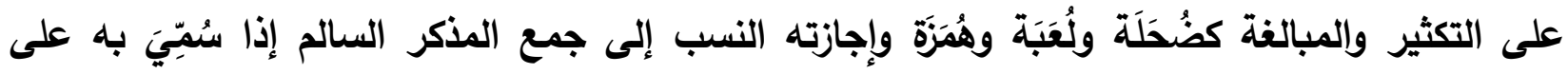

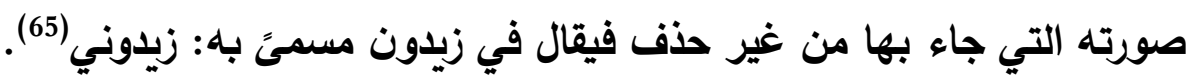
والقياس في كثير من قرارات المجمع مبني على إلحاق الصيغ والمشتقات غير المنقولة بالصئ بلصئ

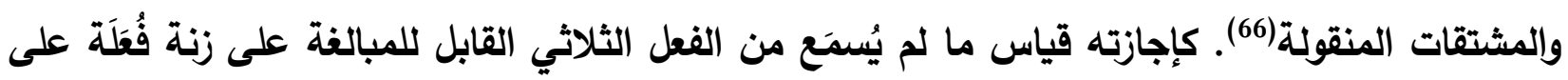

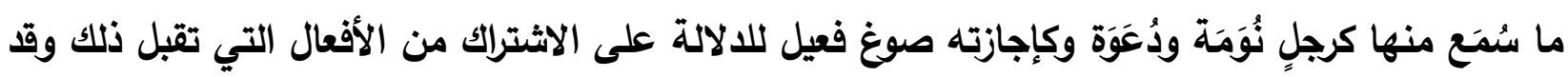

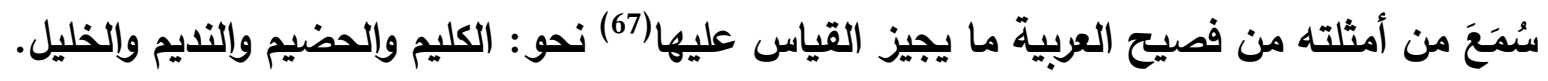
ويمكن تفسير القياس الذي جاءت به قرارات المجمع بأحد المعنيين:

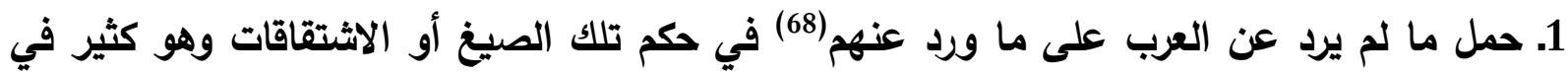
قياسات المجمع؛ لأنّ السماع إذا ورد بثيء لم يبقَ غرضٌ وراء القياس، قال ابن جني: 
״إّاّ أنّ الاستعمال إذا ورد بشيء أخذ به وترك القياس؛ لأنّ السماع يبطل القياسه (69).

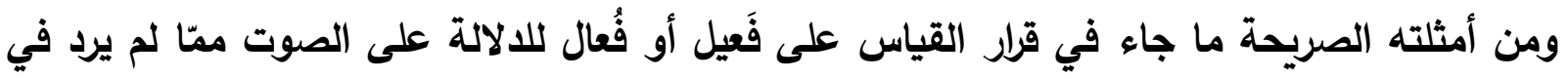
اللغة مصدر للالالة على هذا المعنى(70). ولو لم يصرّح بهذا المعنى فإنّه يحمل عليه لأنّه الكثير وهو الأصل فيه كقرار إجازة ما ينشأ من كلمات

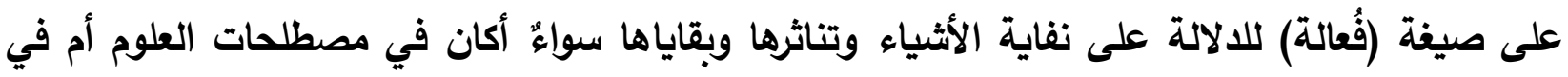

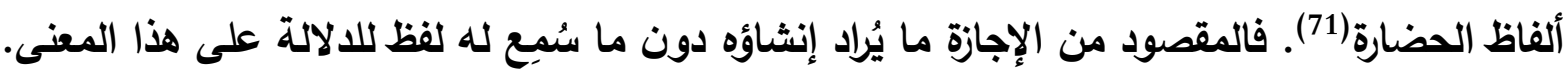

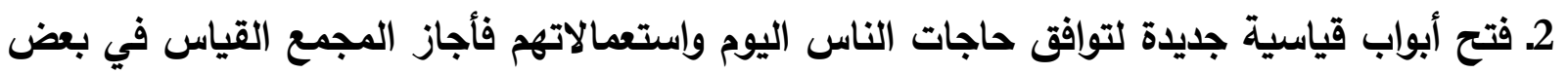
الصيغ على زنةٍٍ ما مع ورود السماع بوزنٍ آخر سواء أكان مقيساً أم غير مقيس ومن أمثلته أن العلماء

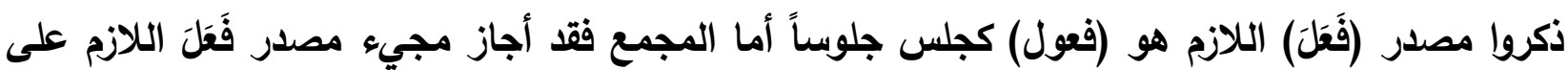

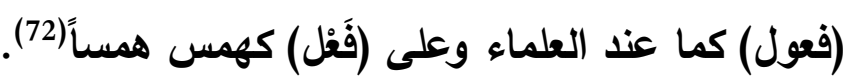
والمجمع ينظر للقياس عن طريق المقيس عليه فإذا كان جائزاً عند بعض العلماء أو وردت فيه

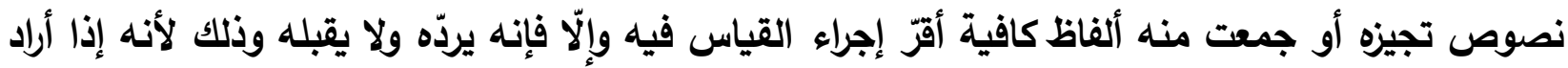

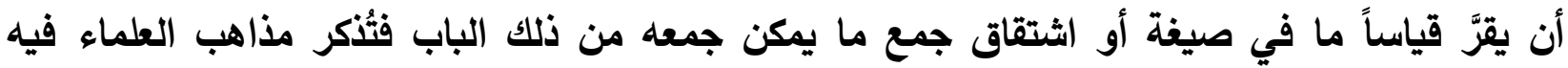

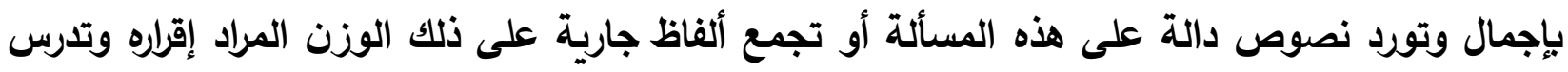
هذه أو تلك في اللجنة ثم المجلس ثم المؤتمر .

ثانياً: الاعتداد بالقليل من المسموع:

يُعبّر اللغويون بالقليل ويريدون به ما يقابل الكثير لكن لم يُعيِّن أحدٌ منهم كمية القليل وإلكثير، ولعلَّ مرد ذلك إلى كون المصطلحات المستخدمة في الدلالة على كثرة المنقول وقّلته في المسألة تعود إلى أنَّ: المطرّد الثائع، والغالب والكثير والقليل والثاذ والنادر، مصطلحات تقديريّة تختلف باختلاف المسموع من

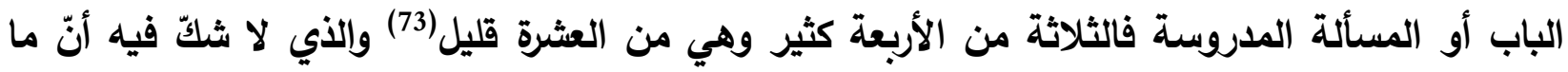
خالف الكثير في مسألةٍٍ ما يُعَدُّ قليلاً.

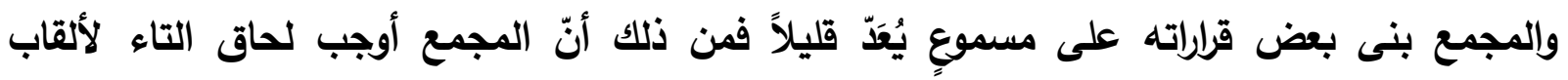
المناصب والأعمال في وصف المؤنث نحو: فلانة وكيل فلان وشاهده، فأوجب أن يقال: وكئ وكيلة فلان أنان

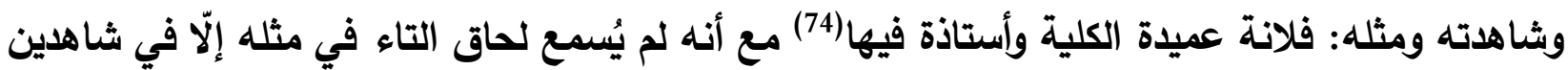
أو ثلاثة، والكثير عن العرب عدم لحاقها لله. 


\section{ثالثاً: إختيار الرأي الأسهل في المسألة:}

زخرت كتب اللغويين بالاختيارات والترجيحات ولثهم فيها اعتبارات متعددة فمنهم مَن يرجّح لاليل منقول

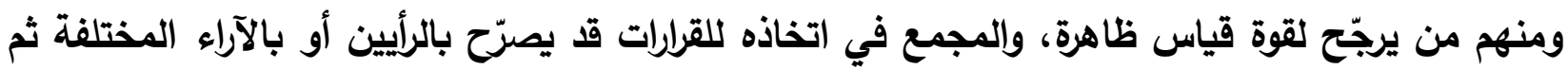
ينصّ على اختيار أحدهما ومن ذلك إجازته لحاق تاء التأنيث (مفعيلاً) صفة للمؤنث كمسكينة (75).

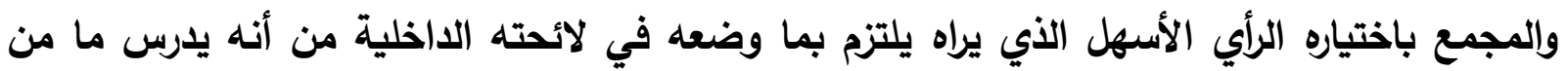

شأنه تيسير قواعد الصرف(76).

\section{رلبعاً: مراعاة حاجة الكُتّاب والمتكلّمين:}

فمن ذلك أنه وسَّع من باب القياس في بعض الصيخ كصياغة مَفْعَة من أسماء الأعيان الثلاثية

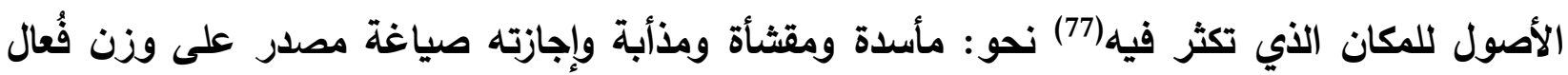

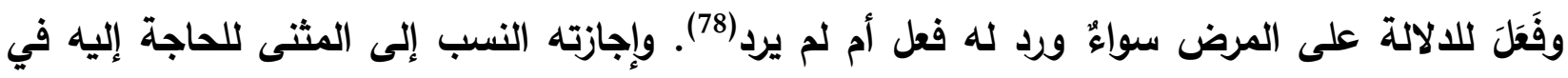
بعض المصطلحات العلمية(79).

هذه هي أهم الأسس التي اعتمدها مجمع اللغة العربية بالقاهرة في إصدار القرارات التي تتعلق بعلوم

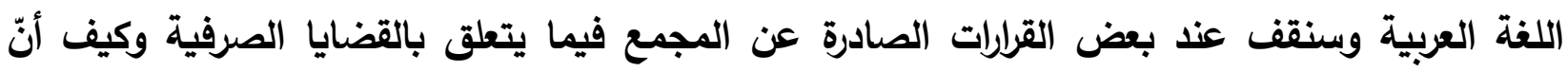
المجمع وظّف هذه الأسس لإصدار قراراته ونرى مدى التيسير المستفاد من هذه القرارات.

\section{أولاً: الميل نحو اختصار الكلمات وتثذييها}

يسعى هذا السلوك اللغوي إلى تقصير الكلمات بأن يدمج كلمتين أو أكثر في كلمة واحدة سعياً للاختصار وتخفيفاً على اللسان وهو ما يُعرف في الصرف العربي باسم (النحت) أو (الاثتقاق الكُبّار)(80) وهذه ظاهرة معروفة عند علماء العربيّة ولها ضوابط متعلقة بنوع الكلمة من ناحية كونها اسماً أو فعلاً

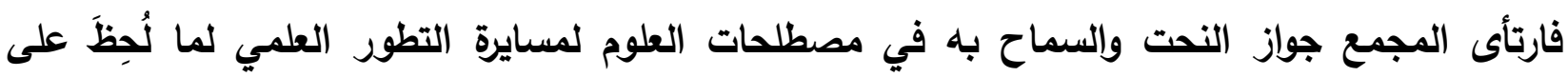
المصطلحات العلميّة تكوّنها من أكثر من كلمة قرّ المجمع جواز نحتها على وفق الضوابط بغية التيسير

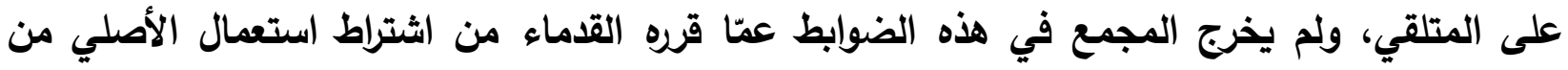

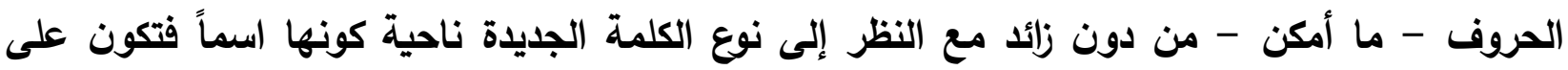
الوزن العربي ويكون الوصف منه بإضافة ياء النسب إليه مثل كلمة (حضرميّ) من حضرموت وأنفمي من

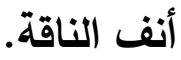
أو من ناحية كونها فعلاً فيكون وزن الفعل الجديد المنحوت على وزن (فعل) إن كان متعديَّاً و (تفعلل) 
إن كان لازماً فيكون مصدرها (فَمْلَلَة) و(تَفَعُلْل) بحسب القياس، إلّا أنّ مجمع اللغة العربية نحا في هذا

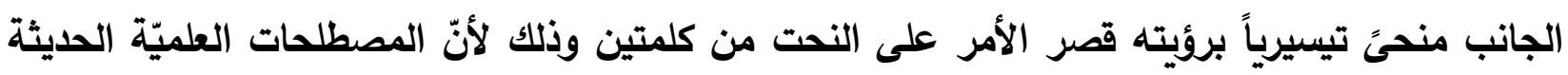

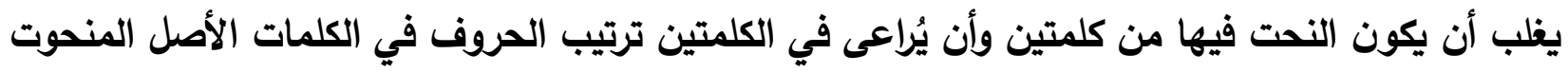

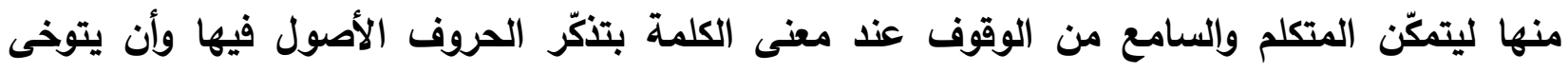

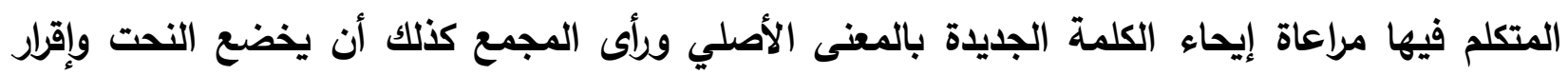

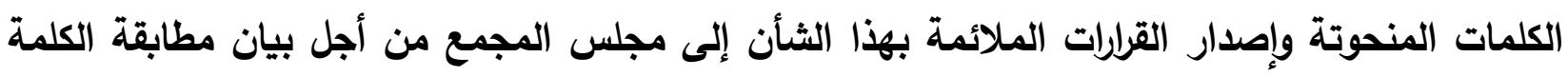
المنحوتة لثرائط النحت ولئلا تكثر القواعد في هذا المجال ممّا قد يعسّر على المتكلم العمل بهذه القرارات

وأن تكون القرارات موافقة للحسّ اللغوي(81). من شأن مثل هذا السلوك اللغوي أن يعمل على مواكبة اللغة العربيّة للتطور العلمي ولاسيما في العلوم الحديثة المعرّبة مما ييسّر على المتكلّم استعمال لغته الأم في التعبير عن العلوم والأفكار المستحدثة

الوافدة إلينا.

\section{ثانياً: إيجاد كلمات جديدة لصيخٍ قديمة}

لقد سعى المجمع إلى التوسّع في إيجاد كلمات جديدة لم تُستعمل قديماً قياساً على صيغ قديمة للدلالة على المعنى نفسه من غير أن يكون ثمة مسموع آخر لهذه الصيغة يدل على المعنى نفسه. مثل صيغة إنى

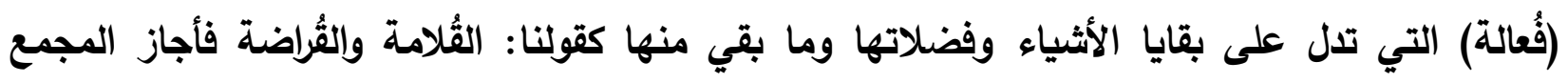
القياس على هذه الصيغة بإنثاء كلمات جليدة للدلالة على المعنى ذاته مثل: كلمة القُمامة للدلالة على الاتلى

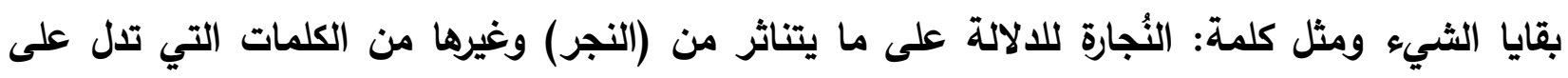
المعنى ذاته مثل : الجُزارة والسُّلاخة والأَّانة. ولكن المجمع اشترط لذلك شرطين ينبغي مراعاتهما عند استحداث الكلمات لئلا تُصاب اللغة بالترهل،

وهذان الثرطان هما:(82)

1. ألّا يكون للكلمة صيغة ثانية دالة على المعنى نفسه لأنّ من شأن ذلك أن يُربك المتكلّم إذ لا يتسنّى له معرفة الصيغ المستعملة للدلالة على المعنى ويجعل اللغة مترهلة بكثرة مفرداتها التي يمكن الاستغناء عنها ومثال ذلك:

كلمة (المُخاطة) لا يجوز استعمالها للالالة على ما بقي من أخلاط الأنف وتماتّ منه لأنّ لهذا المعنى

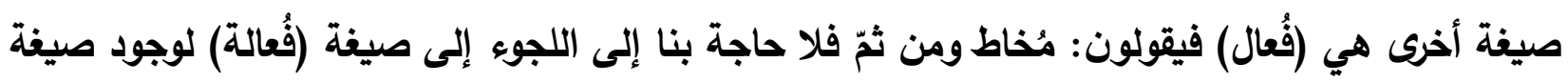
أخرى تلل على المعنى ذاته. 
وليس هذا الثرط بعيداً عن السمت اللغوي ومقررات العلماء اللغويين القدماء أنفسهم إذ جاء في المنصف(83): (إذا ورد السماع بثيء لم يبقَ غرض مطلوب وعُدِل عن القياس إلى السماع). 2. أن تظهر حاجة حقيقية للدلالة على ذلك المعنى؛ لأنّ من أهداف اللغة أن تعبّر عن المعاني فئن إنْ

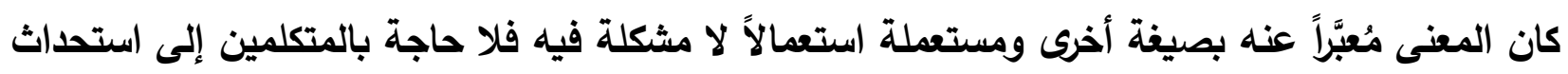
صيغ أخرى. إنّ من شأن هذا الاستحداث أن يفتح أمام المتكلّم مجالات واسعة للاستعمالات اللغوية فيخرج به من ضيق الاستعمال إلى رحابته لتواكب لغة المتكلم ما يستجد من معانٍ تفرزها الحضارة المدنية والتطور العلمي. 
إذ أَزْفا أن نطوي الصفحات الأخيرة من البحث لا بُّ من ثمرة يجنيها من يتصدّى لهذا الضرب من

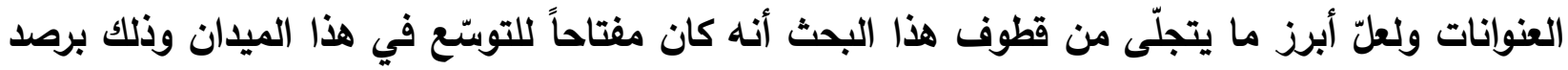

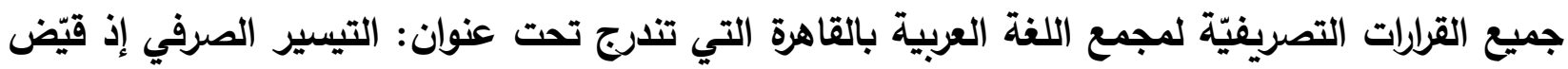

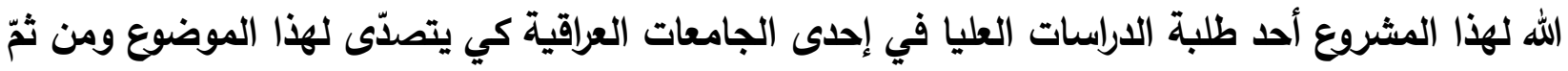
يكون عنواناً لأطروحته. وأبرز ما يمكن إجماله من نتائج هذا البحث يتمثّل فيما هو آتٍٍ: • مثلما توجد عند الناس ثقافات علمية وتأريخية وسياسية واقتصادية واجتماعية في المجتمع لا

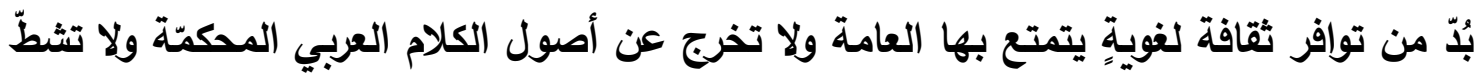
في التركيب بعيداً في الهجنة، وفي الوقت نفسه تواكب تطور العلوم التقنية والمعارف الإنسانية، توانه بَيََ أنَّ المختص باللغة العربية يتوجّب عليه فهم دقائقها ومعرفة أصولها وما بُنيت عليه الكلمات والعبارات إذ هذا من وكده وشأنه. باته التيسير يواكب مستجدات العصر: السياسية والاجتماعيّة والاقتصادية، فيضع لها المشرِع اللغوي قواعد تواكب هذه المستجدات وإن لم يجد فيقترح لها صيغاً تواكب هذه المستجدات ويعرض هذه القواعد على المتلقي ليجد لها في نفسه قبولاً. التيسير: بين رافضٍ وقابلٍ به، فمن قَبل به كانت لله مسوّغاته ومن رفضه كانت له له مسوّغات،

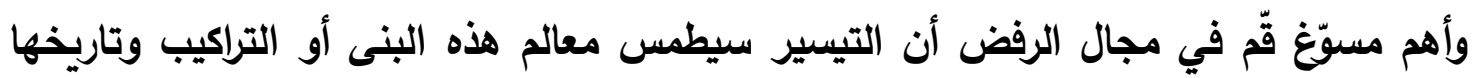

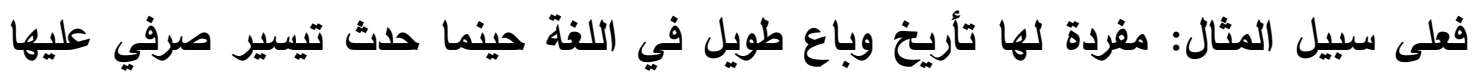

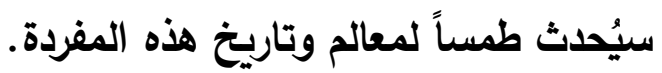
لكن يُرَّد على هذا الرأي أن المختص هو من سيقف متأيخلاً في تأريخ هذه المفردة، والعامة لا

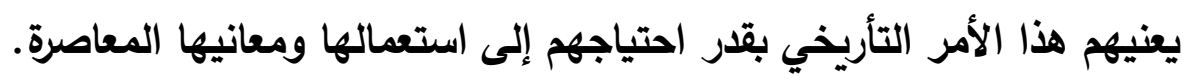

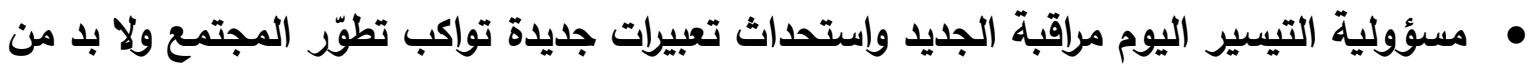
توفير غطاء مشروع لهذا الاستحداث وهذا الغطاء يُستمد من التراث اللغوي القديم، فمهمّة التيسير تفعيل التراث بما توفّر لذلك التراث من رؤى وأفكار واختلاف وجهات النظر بين العلماء الأقدمين، والتيسير قد نهض بالتراث وأماط اللثام عن المسكوت عنه من التراث. 
• وجدنا أنّ حرص مجمع اللغة العربية بالقاهرة على تيسير الصرف العربي في كثير من قراراته،

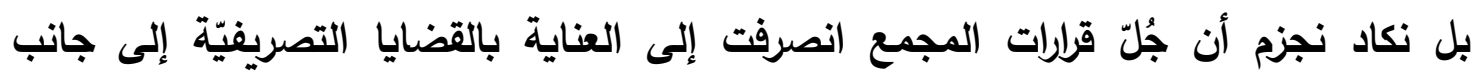
الاهتمام بالقضايا النحوية، وقد أثرنا في أثناء البحث إلى علّة كثرة قرارات المجمع التصريفية بالهية

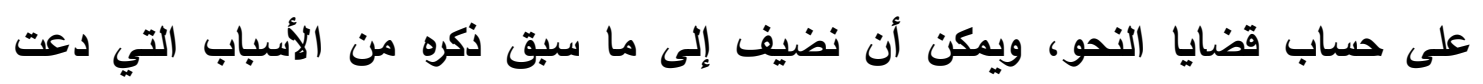

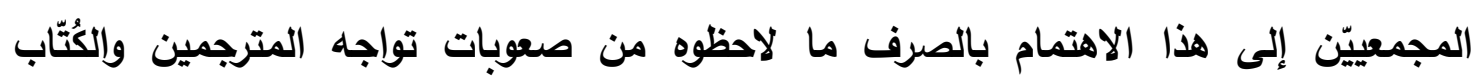

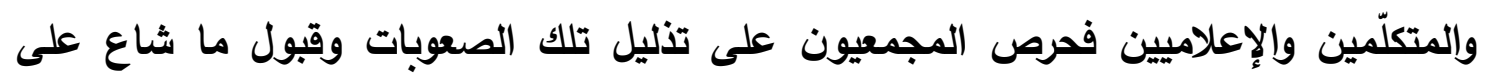

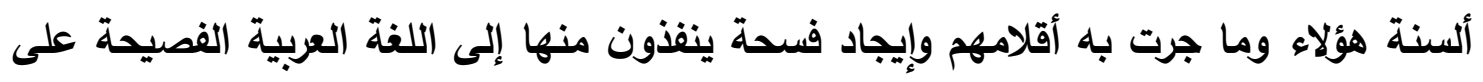
وفق ضوابط محدة لا تخرج عن أُطر الدرس الصرفي الموروث.

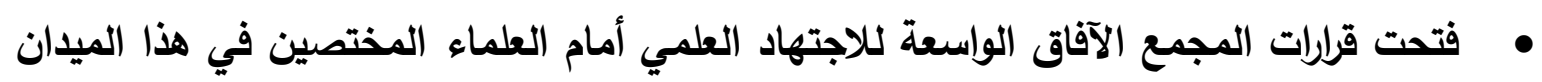

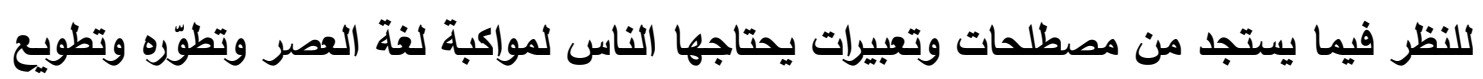
مفردات العربية للوقوف أمام الثورة الصناعية والحضارية وذلك للحفاظ على العربية من الانزواء والانظماس. 


\section{هوامش البحث}

(1) (1) سورة الليل: الآية 7.

(2) سورة الليل: الآية 10.

(3) (3ورة التوبة: الآية 3.

(4) لسان العرب: مادة (يسر) المجلد الخامس عشر 315 - 316، وينظر: معجم مقاييس اللغة، المجلد الساد: 155 $.156-$ (5) ينظر : التوقيف على مهمات التعاريف: 361/1.

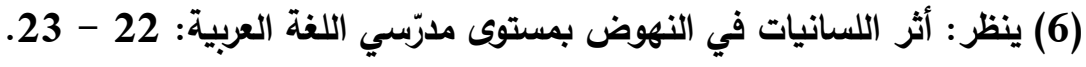

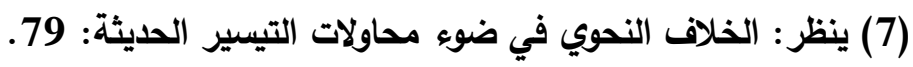
(8) ينظر على سبيل المثال: تجديد النحو، د.شوقي الضيف، في حركة تجديد النحو وتيسيره في العصر الحديث، د. نعمة رحيم العزاوي.

(9) ينظر: الخلاف النحوي في ضوء محاولات التيسير الحايثة: 80.

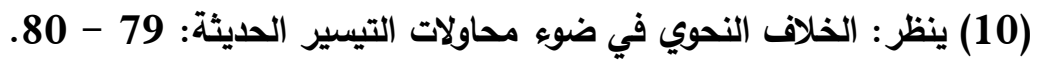
(11) فكرة التيسير في الدرس النحوي الحيث: 17 - 18 - 18.

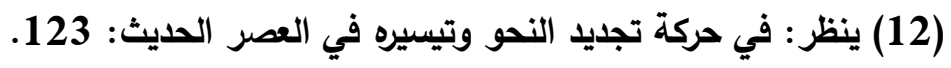

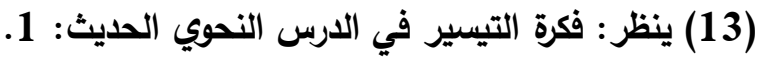

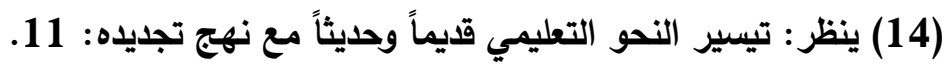

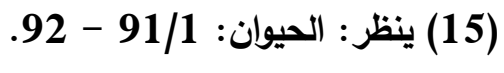
(16) (16) الرماني النحوي: 73، 229. (17) (17) ابن الحاجب النحوي: 55.

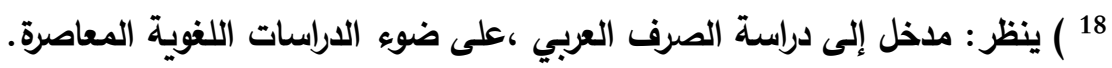

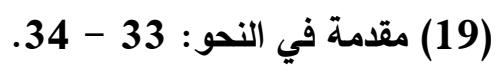

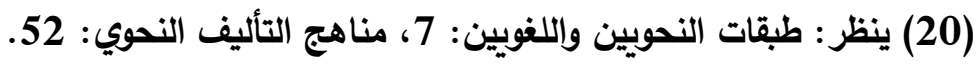
(21) ينظر : مناهج التأليف النحوي: 53.

(22) (23) الخصائص: 34/1.

(23) ينظر : مناهج التأليف النحوي: 168 (24)

(24) ينظر : الارس النحوي في بغداد: 160.

(25) رسائل الجاحظ: 38/3.

(26) ينظر: الخلاف النحوي في ضوء محاولات التيسير الحديثة: 128. 
(27) - (28) - الرد على النحاة: 65.

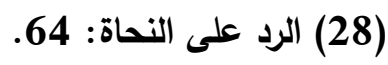

(29) الرد على النحاة: 135 - 137 النحاة: 137.

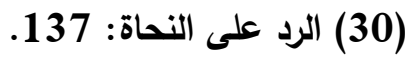

(31) ينظر: فكرة التيسير في الارس النحوي الحليث: 4 - 5 - 5.

(32) هو الباحث عبد الوارث مبروك في كتابه: في إصلاح النحو العببي: 43 (31)

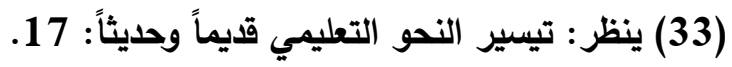

(34) في حركة تجليد النحو وتيسيره في العصر الحايث: 34 (334)

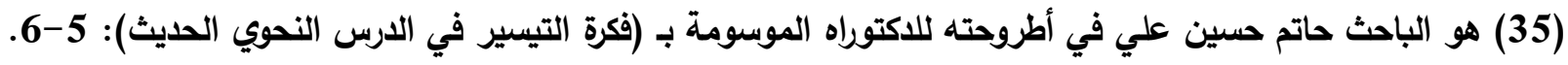

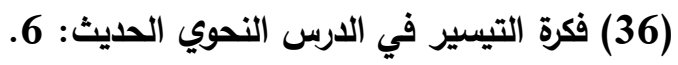

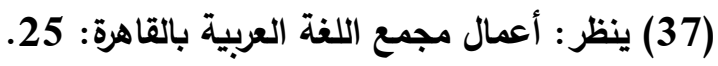

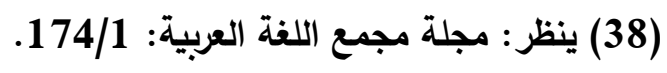

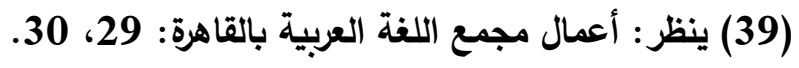

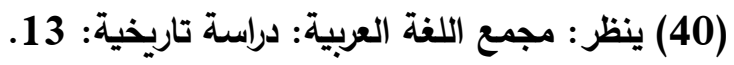

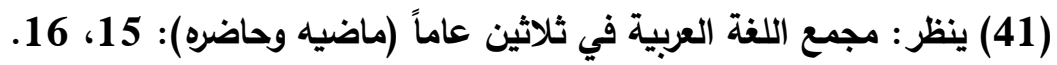

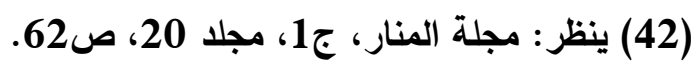

(43) ينظر : مجلة اللغة العربية: 22/1.

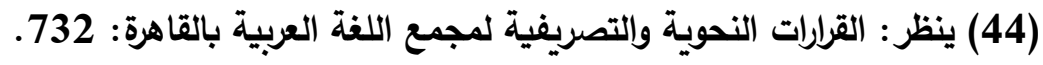

(45) ينظر على سبيل المثال: تصريف الأسماء 77-79، الأسماء العببية في التصريف: 144-145، التباء التبيان في

تصريف الأسماء: 61.

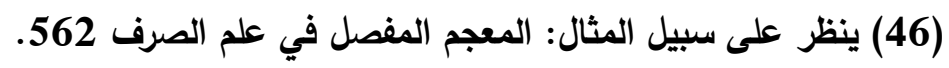

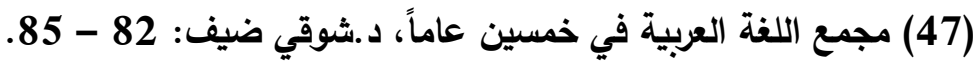

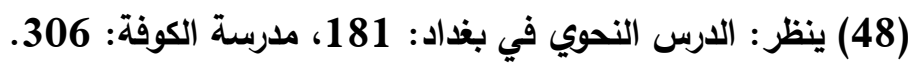

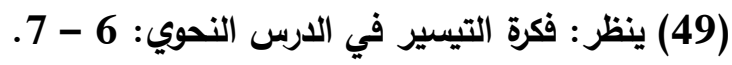

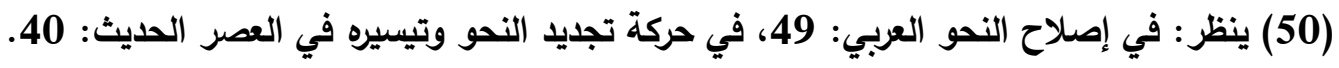

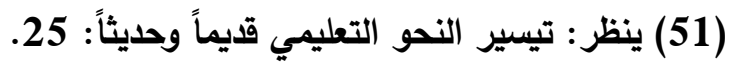

(52) ينظر : في إصلاح النحو العربي: 50 : 50.

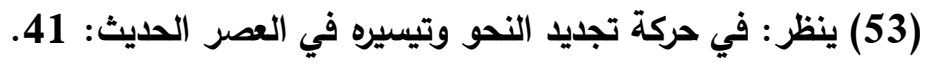

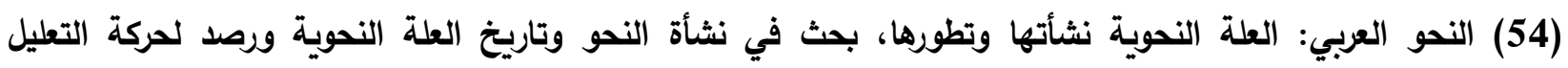
وتطورها حتى القرن العاشر للهجرة، مازن المبارك: 3-4. 
(55) البحث الصرفي في الاراسات اللغوية العربية الحديثة، أطروحة دكتوراه، نسرين عبد الله شنوف، أ، ب (المقدمة).

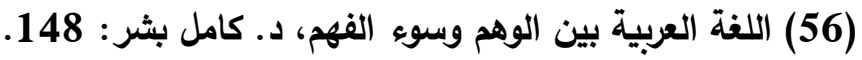

(57) محاضرات مجمعية، د.شوقي ضيف: 66 (5)

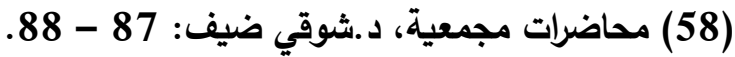
(59) تنمية اللغة العربية في العصر الحديث: 256. (60) ينظر: أشتات مجتمعات في اللغة والأدب: 51 الكئ 61

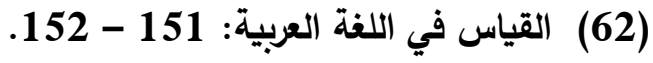

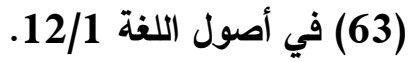

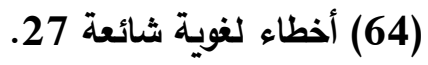

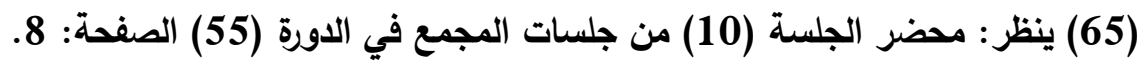

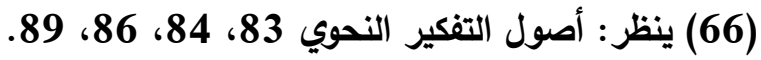
(68) ينظر : مجموعة القرارات العلمية (في خمسين عاماً): 53 (66) (68) ينظر : القياس في اللغة العربية 176. 279/1 (69) المنصف : 270)

(70) ينظر : مجموعة القرارات العلمية (في ثلاثين عاماً): 26.

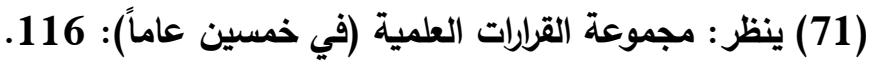

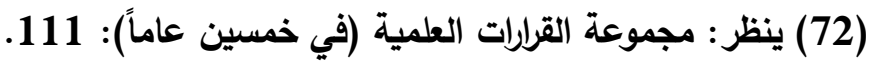

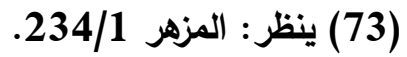
(74) ينظر: في أصول اللغة $59 / 3$ (75) (75) ينظر: في أصول اللغة 50/3.

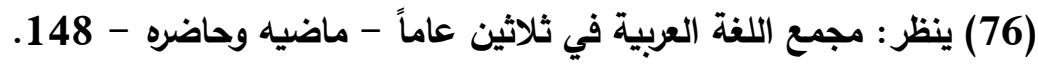

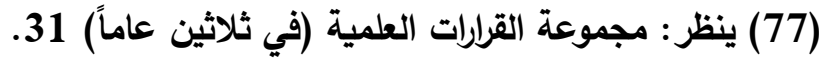

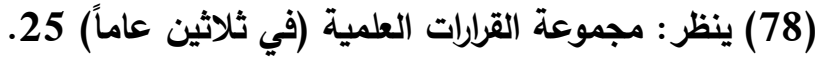
(79) ينظر : في أصول اللغة (78/3.

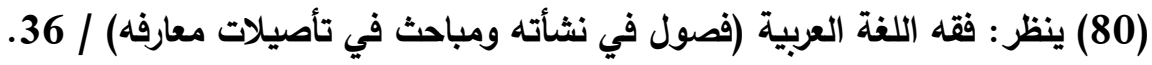

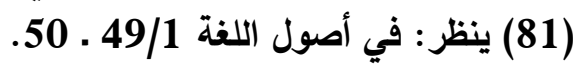

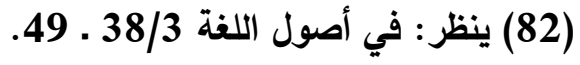
(83) المنصف: 279/1. 
2 2 2 ـ ابن الحاجب النحوي، آراؤه ومذهبه، د. طارق عبد عون الجنابي، بذاد، 1973 ـ 1974م.

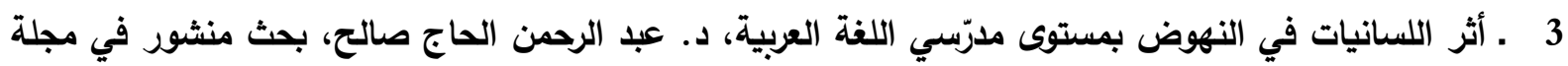

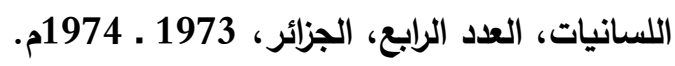
4 5 6 7 8

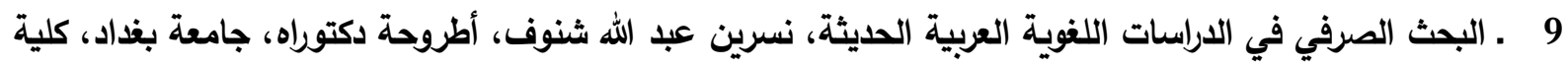

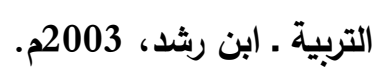

10 ـ التبيان في تصريف الأسماء، أحمد حسن كحيل،ط7, دار البيان العببي، القاهرة، 1402هـ.

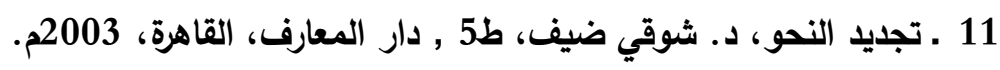

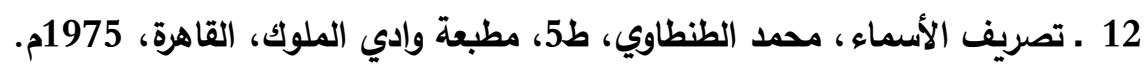

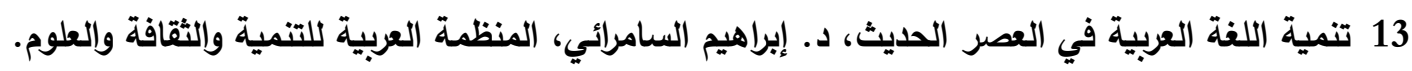
14 ـ التوقيف على مهمات التعاريف، محمد بن عبد الرؤوف المناوي (ت التعائ 1031هـ)، تحقيق: د. محمد رضوان الداية، دار الفكر المعاصر، بيروت، 1410هـ.

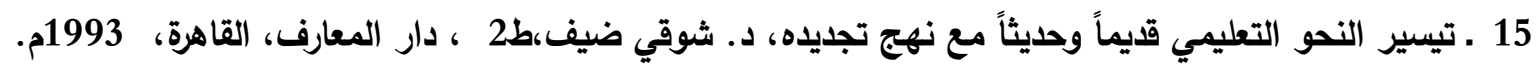
16 الحيوان، أبو عثمان عمرو بن بحر الجاحظ (ت 255هـ)، تحقيق: عبد السلام هارون، مكتبة مصطفى البابي

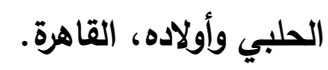

17 ـ الخصائص، أبو الفتح بن جني (ت 392هـ)، تحقيق: محمد علي النجار، دار الهاى للطباعة والنثر، بيروت.

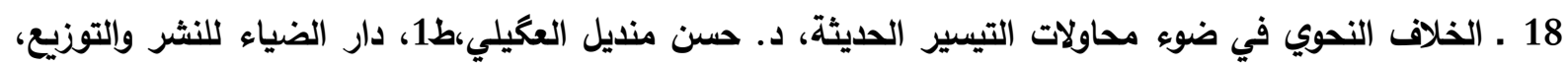

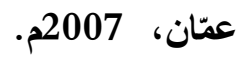

19 الدرس النحوي في بذاد، د. مهاي المخزومي، وزارة الإعلام العراقية، مطبعة السعدون، بذاد، 1974م.

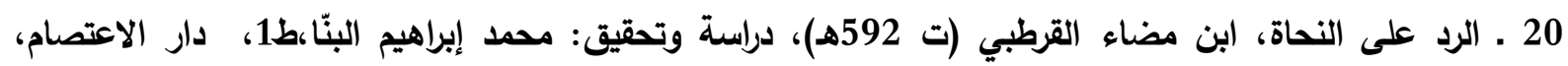

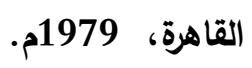

21 ـ رسائل الجاحظ، أبو عثمان عمرو بن بحر (ت 255هـ)، تحقيق: جمعة حسن السندوبي، مصر.

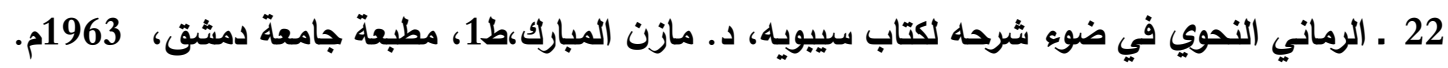


23 ـ طبقات النحويين واللغويين، أبو بكر محمد بن الحسن الزبيدي (ت 379ه)، تحقيق: محمد أبو الفضل إبراهيه، القاهرة، 1954م.

24 ـ فقه اللغة العربية (فصول في نثأته ومباحث في تأصيلات معارفه)، د. عبد الحسين مهدي عواد،12 ، مؤسسة

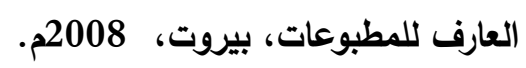
25 ـ فكرة التيسير في الدرس النحوي الحديث، حاتم حسين علي، أطروحة دكتوراه، جامعة بذاد، كلية الآداب، .2005

26 ـ في إصلاح النحو العبي، عبد الوارث مبروك، ط1، 1985م.

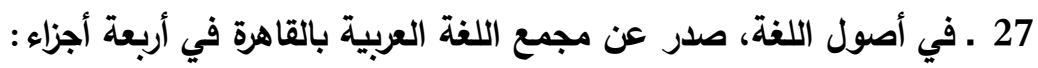

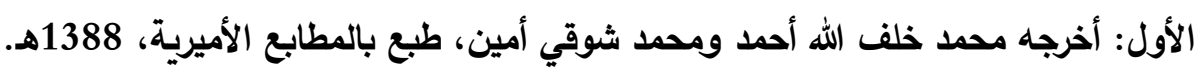

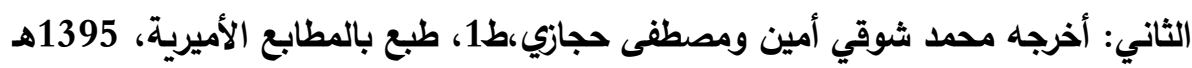

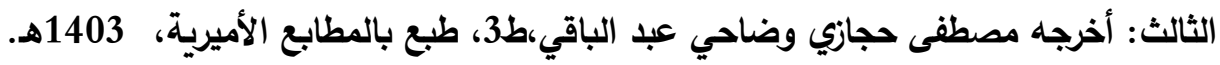

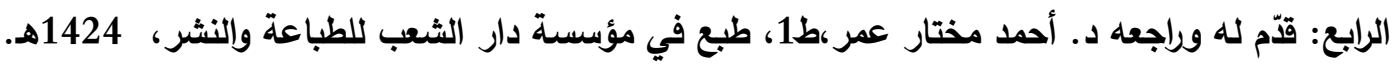

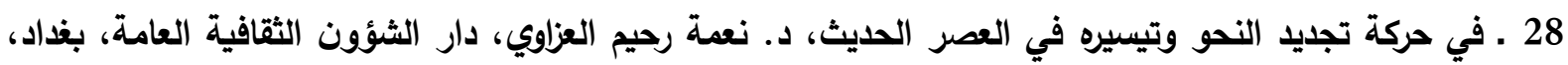
.1995 29 ـ القرارات النحويّة والتصريفيّة لمجمع اللغة العربية بالقاهرة ، جمعاً ودراسةً وتقويماً .، خالد بن سعود بن فارس العصيمي،ط2، دار التدمريّة، السعودية، 20092.

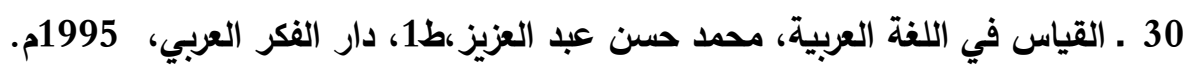

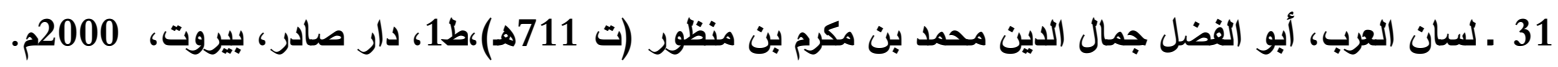

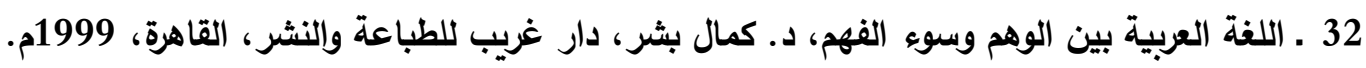
33 ـ مجلة مجمع اللغة العربية بالقاهرة، الجزيء الأول.

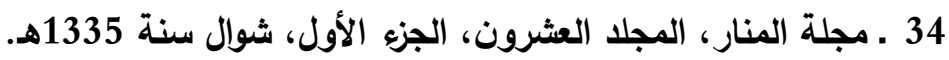

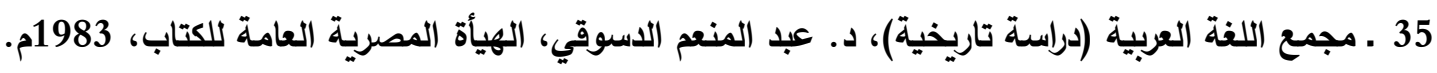

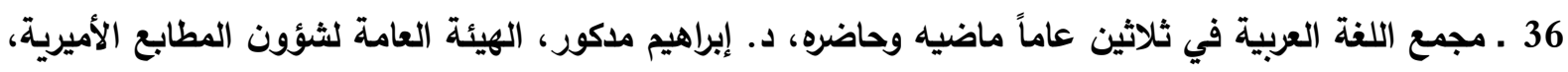

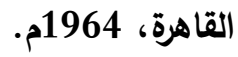

37 ـ مجمع اللغة العربية في خمسين عاماً، د. شوقي ضيف، منشورات مجمع اللغة العربية، القاهرة، ط1، 1984م، دمات

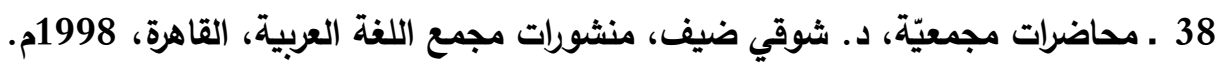

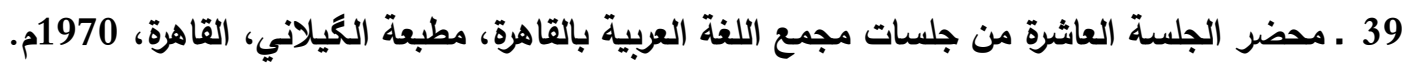

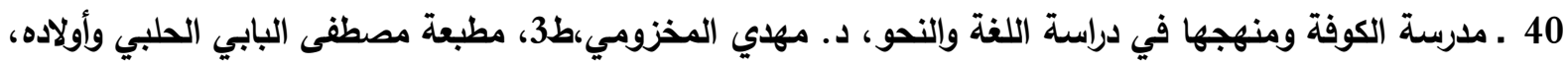
القاهرة، 1958م. 41 ـ المزهر في علوم اللغة وأنواعها، جلال الدين بن أبي بكر السيوطي (ت 911هـ)، تحقيق: محمد أحمد جاد المولى،4،، دار الكتب العلمية، بيروت، 1958م. 


$$
42 \text { ـ المعجم المفصل في علم الصرف، راجي الأسمر،33، دار الكتب العلمية، بيروت، } 2009 \text { 2009. }
$$

43 ـ معجم مقاييس اللغة، أبو الحسين أحمد بن فارس بن زكريا (ت 395هـ) تحقيق: عبد السلام محمد هارون، دار

$$
\text { الجيل، بيروت، 1999م. }
$$

44 ـ مقدمة في النحو، خلف الأحمر (ت 180هـ)، تحقيق: عز الدين التنوخي، مطبوعات مديرية إحياء التراث القديم،

$$
\text { دمثق، 1961م. }
$$

45 ـ مناهج التأليف النحوي، د. كريم حسين ناصح،ط1، دار صفاء للنشر والتوزيع، عمّان، 2007م.

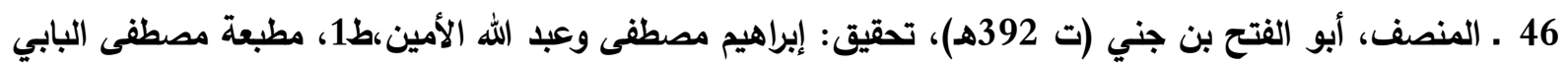

$$
\text { الحلبي وأولاده، 1954م. }
$$

47 ـ النحو العربي، العلة النحوية نثأتها وتطورها (بحث في نثأة النحو وتأريخ العلة النحوية ورصد لحركة التعليل

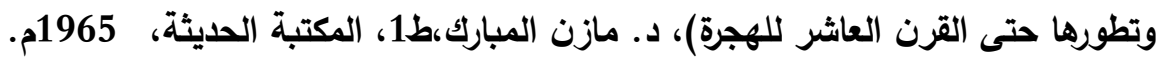

